\title{
Early neuronal accumulation of DNA double strand breaks in Alzheimer's disease
}

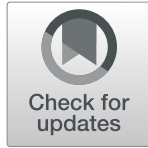

Niraj M. Shanbhag ${ }^{1,2 \dagger}$, Mark D. Evans ${ }^{1 \dagger}$, Wenjie Mao ${ }^{1 \dagger}$, Alissa L. Nana ${ }^{2,3}$, William W. Seeley ${ }^{2,3}$, Anthony Adame ${ }^{4}$, Robert A. Rissman ${ }^{4}$, Eliezer Masliah ${ }^{4,5}$ and Lennart Mucke ${ }^{1,2^{*}}$ (i)

\begin{abstract}
The maintenance of genomic integrity is essential for normal cellular functions. However, it is difficult to maintain over a lifetime in postmitotic cells such as neurons, in which DNA damage increases with age and is exacerbated by multiple neurological disorders, including Alzheimer's disease (AD). Here we used immunohistochemical staining to detect DNA double strand breaks (DSBs), the most severe form of DNA damage, in postmortem brain tissues from patients with mild cognitive impairment $(\mathrm{MCl})$ or $A D$ and from cognitively unimpaired controls. Immunostaining for $\gamma \mathrm{H} 2 \mathrm{AX}$ - a post-translational histone modification that is widely used as a marker of DSBs-revealed increased proportions of $\mathrm{YH} 2 \mathrm{AX}$-labeled neurons and astrocytes in the hippocampus and frontal cortex of MCl and AD patients, as compared to age-matched controls. In contrast to the focal pattern associated with DSBs, some neurons and glia in humans and mice showed diffuse pan-nuclear patterns of $\mathrm{YH} 2 \mathrm{AX}$ immunoreactivity. In mouse brains and primary neuronal cultures, such pan-nuclear $\mathrm{YH} 2 \mathrm{AX}$ labeling could be elicited by increasing neuronal activity. To assess whether pan-nuclear $\gamma \mathrm{H} 2 \mathrm{AX}$ represents DSBs, we used a recently developed technology, DNA damage in situ ligation followed by proximity ligation assay, to detect close associations between $\mathrm{\gamma H} 2 \mathrm{AX}$ sites and free DSB ends. This assay revealed no evidence of DSBs in neurons or astrocytes with prominent pan-nuclear $\gamma \mathrm{H} 2 \mathrm{AX}$ labeling. These findings suggest that focal, but not pan-nuclear, increases in $\mathrm{YH} 2 \mathrm{AX}$ immunoreactivity are associated with DSBs in brain tissue and that these distinct patterns of $\mathrm{\gamma H} 2 \mathrm{AX}$ formation may have different causes and consequences. We conclude that $\mathrm{AD}$ is associated with an accumulation of DSBs in vulnerable neuronal and glial cell populations from early stages onward. Because of the severe adverse effects this type of DNA damage can have on gene expression, chromatin stability and cellular functions, DSBs could be an important causal driver of neurodegeneration and cognitive decline in this disease.
\end{abstract}

Keywords: Alzheimer's disease, Astrocytes, DNA damage, 53BP1, үH2AX, Neurons

\section{Introduction}

Genomic integrity is necessary for normal gene expression and cellular functions. However, all cells in the body are continually subjected to DNA damage from endogenous and exogenous sources $[16,53,65]$. The cellular DNA repair machinery evolved to reverse this damage. Nonetheless, aging is associated with the accumulation of DNA damage across diverse cell types, tissues and animal species, and much evidence suggests that DNA damage accelerates aging and related impairments $[55,57,71,83]$.

\footnotetext{
* Correspondence: lennart.mucke@gladstone.ucsf.edu

${ }^{\dagger}$ Niraj M. Shanbhag, Mark D. Evans, and Wenjie Mao contributed equally to this work.

${ }^{1}$ Gladstone Institute of Neurological Disease, San Francisco, CA 94158, USA

${ }^{2}$ Memory and Aging Center, Department of Neurology, University of

California San Francisco, San Francisco, CA 94158, USA

Full list of author information is available at the end of the article
}

The ability to maintain genomic integrity is probably most important for postmitotic cells that are long lived such as neurons. Unable to divide, and for the most part irreplaceable, the majority of neurons have to rely on their genetic material for the lifetime of an organism. Furthermore, neurons have a highly active metabolism and produce large quantities of free radicals, which can cause oxidative DNA damage [25]. Notably, increased levels of DNA damage in aging brains are associated with the reduced expression of essential genes, including genes involved in neuronal plasticity [62]. Neuronal DNA damage is further exacerbated in many neurodegenerative disorders $[6,42,65,92]$, which may contribute to the extensive changes in gene expression and neuronal loss found in these conditions.

(C) The Author(s). 2019 Open Access This article is distributed under the terms of the Creative Commons Attribution 4.0 International License (http://creativecommons.org/licenses/by/4.0/), which permits unrestricted use, distribution, and 
Numerous studies have reported increased evidence for oxidative DNA damage in the brains, cerebrospinal fluid, and peripheral cells of patients with mild cognitive impairment (MCI) or Alzheimer's disease (AD) [6, 22, 31, 58-60, 115]. This DNA damage has been attributed to increased production of free radicals and to deficits in relevant DNA repair pathways $[8,58]$. Most often, oxidative DNA damage appears to consist primarily of DNA base modifications and single strand breaks [12, 27].

Interestingly, much less is known about the association between AD and DNA double strand breaks (DSBs), the most deleterious form of DNA damage. In dividing cells, unrepaired DSBs can lead to cell cycle arrest and cell death [120], while the inaccurate repair of DSBs can lead to mutations, deletions, or chromosomal translocations $[20,110]$. Unlike dividing cells, which can utilize sister chromatids to repair DSBs in an error-free manner by homologous recombination, postmitotic neurons must resort to more error-prone mechanisms of DSB repair such as nonhomologous end joining (NHEJ) [39, 51]. Thus, DSBs could be particularly detrimental to neuronal function and survival, and thereby promote the development of age-related cognitive decline or disease [65].

The response to DSB formation involves the rapid post-translational modification and recruitment of multiple proteins to broken DNA ends and the surrounding chromatin. One of the earliest events in this process is the phosphorylation of the histone variant $\mathrm{H} 2 \mathrm{AX}$ at serine 139, which occurs at multiple sites for up to megabases of chromatin surrounding the break site [5, 35, 91, 99]. Nuclear foci containing high concentrations of phospho-S139-H2AX, termed $\gamma \mathrm{H} 2 \mathrm{AX}$, can be visualized by immunohistochemistry and are widely used as putative evidence for the presence of DSBs [54, 91]. Many DSB response proteins, including 53BP1, are also recruited to and retained at sites of DSBs at high concentrations and can be visualized with similar methods.

Current reports of DSBs in the brains of patients with $\mathrm{AD}$ are conflicting. One population-based study demonstrated $\gamma \mathrm{H} 2 \mathrm{AX}$ immunoreactivity in neurons and glia of patients with low levels of AD pathology and suggested a trend toward decreasing $\gamma \mathrm{H} 2 \mathrm{AX}$ levels as $\mathrm{AD}$ pathology increased [100]. The same group showed that $\gamma \mathrm{H} 2 \mathrm{AX}$ immunoreactivity could be detected in brain cells of aged people with little or no $\mathrm{AD}$ pathology, and that the number of $\gamma \mathrm{H} 2 \mathrm{AX}$-positive neurons inversely correlated with bedside cognitive test scores [101]. In contrast, another group found evidence for $\gamma \mathrm{H} 2 \mathrm{AX}$ immunoreactivity in astrocytes, but not neurons, in brains from patients with advanced AD pathology [76].

Notably, these studies used immunoperoxidase staining to detect $\gamma \mathrm{H} 2 \mathrm{AX}$ and showed diffuse, pan-nuclear staining patterns, as opposed to the focal pattern seen at genuine DSBs [54, 90]. More recently, Mano and colleagues complemented $\gamma \mathrm{H} 2 \mathrm{AX}$ immunoperoxidase staining with the neutral comet assay $[79,80,102]$ to demonstrate increased levels of DSBs in a small number of AD patients [68]. However, the neutral comet assay does not allow for a determination of the cell types that harbor DSBs, can be confounded by topological changes in DNA induced by experimental conditions [3], and relies solely on the presence of broken DNA strands, some of which might result from postmortem tissue degradation.

In this study, we used the well-established neutral comet assay, as well as optimized immunohistochemical approaches, novel technologies and high-resolution microscopy on postmortem brain tissues from two independent human cohorts to determine whether $\mathrm{AD}$ and $\mathrm{MCI}$, a frequent harbinger of $\mathrm{AD}[46,67]$, are associated with an increase in neuronal DSBs. We used mouse and cell culture models to validate our DSB detection methods and to differentiate cellular staining patterns that represent DSBs from those caused by other processes that could confound the interpretation of results obtained by widely used methods.

\section{Materials and methods}

Human postmortem tissues and neuropathological diagnosis

Cohort 1 consisted of 13 cases (Additional file 1: Table S1). Tissues were obtained from the University of California, San Francisco (UCSF) Neurodegenerative Diseases Brain Bank. Before their death, subjects had been studied neurologically and psychometrically at the UCSF Memory and Aging Center. Authorization for autopsy was provided by all subjects or their next-of-kin in accordance with the Declaration of Helsinki, and all procedures were approved by the UCSF Committee on Human Research. At autopsy, the cerebrum was cut fresh into $1 \mathrm{~cm}$ thick coronal slices and fixed for $48-72 \mathrm{~h}$ in buffered $10 \%$ formalin. Neuropathological diagnoses were made in accordance with consensus diagnostic criteria [33, 70] using histological and immunohistochemical methods as described [108]. Cases were selected based on neuropathological diagnosis. Blocks of the inferior frontal gyrus, pars orbitalis were dissected and placed into PBS with $0.02 \%$ sodium azide for storage.

Cohort 2 consisted of 23 cases (Additional file 1: Table S2). Before their death, subjects had been examined neurologically and psychometrically at the Shiley-Marcos Alzheimer's Disease Research Center/University of California at San Diego (ADRC/UCSD). Authorization for autopsy was provided by all subjects or their next-of-kin in accordance with the Declaration of Helsinki, and all procedures were approved by the UCSD Institutional Review Board. At autopsy, brains were processed and evaluated as described [87]. They were divided sagittally. The left hemibrain was fixed in buffered $10 \%$ formalin or $4 \%$ paraformaldehyde (PFA) for 2 weeks for 
histopathological analysis; the right hemibrain was frozen at $-70^{\circ} \mathrm{C}$ for DNA damage in situ ligation followed by proximity ligation assay (DI-PLA). Paraffin sections of formalin-fixed neocortical, limbic and other subcortical tissues were stained with hematoxylin and eosin $(\mathrm{H} \& \mathrm{E})$, or with antibodies against amyloid- $\beta$ (A $\beta)$ or phosphorylated tau (Additional file 1: Table S3), followed by detection of primary antibodies with species-matched secondary antibodies (Agilent/Dako), development with the immunoperoxidase method, and visualization by light microscopy as described [87]. Neuropathological analysis included counting of amyloid plaques and neurofibrillary tangles (per $0.1 \mathrm{~mm}^{2}$ ), and Braak staging $[33,87]$.

\section{Double-immunolabeling and laser scanning confocal microscopy of human brain sections}

For Cohort 1, double-immunolabeling studies were performed on free-floating $30-\mu \mathrm{m}$ microtome sections from the orbitofrontal cortex. Briefly, sections were washed in Tris-buffered saline (TBS), permeabilized in TBS containing $0.5 \%$ Triton X-100 (Sigma-Aldrich) at $4{ }^{\circ} \mathrm{C}$ overnight, and incubated for $15 \mathrm{~min}$ at $110^{\circ} \mathrm{C}$ in citrate buffer $(\mathrm{pH}$ 6.0) for antigen retrieval. They were then incubated in $3 \%$ $\mathrm{H}_{2} \mathrm{O}_{2}$ and $10 \%$ methanol for $15 \mathrm{~min}, 0.1 \%$ Sudan Black (Sigma-Aldrich) in 70\% ethanol for $15 \mathrm{~min}$, and $10 \%$ goat serum in TBS containing $0.1 \%$ Tween-20 (TBST) for $1 \mathrm{~h}$. Anti- $\gamma \mathrm{H} 2 \mathrm{AX}$ and anti-NeuN antibodies (Additional file 1: Table S3) in TBST containing 3\% goat serum were applied first at $4{ }^{\circ} \mathrm{C}$ overnight and then at room temperature for $2 \mathrm{~h}$. Primary antibodies were detected with Alexa Fluor secondary antibodies (Thermo Fisher Scientific) at 1:500 dilution. All sections were processed simultaneously under the same conditions, except that for some sections, TO-PRO-3 (Thermo Fisher Scientific) was used to stain nuclei. Sections were mounted onto glass slides and covered with ProLong Diamond Antifade Mountant (Thermo Fisher Scientific).

Confocal images were acquired from cortical layer II/III with an LSM 880 laser-scanning confocal microscope (Zeiss, Germany) and a 20x objective lens (NA 0.8). Z-stack images were taken with sequential acquisition settings at pixel size of $0.41 \mu \mathrm{m}$. ImageJ software [93] was used to analyze $\gamma \mathrm{H} 2 \mathrm{AX}$ foci. First, the NeuN channel was used to select 50 neurons from a single image per case. In these cells, the $\gamma \mathrm{H} 2 \mathrm{AX}$ channel was then used to calculate the number of $\gamma \mathrm{H} 2 \mathrm{AX}$ foci per nucleus through manual counting. The proportion of neurons with one or more $\gamma \mathrm{H} 2 \mathrm{AX}$ foci was calculated. Neurons with pan-nuclear $\gamma \mathrm{H} 2 \mathrm{AX}$ signals were excluded from the analysis.

For Cohort 2, double-immunolabeling studies were performed on free-floating $40-\mu \mathrm{m}$ vibratome sections from the mid-frontal cortex (Brodmann area 46) and hippocampus as described [87]. Briefly, sections were washed with phosphate-buffered saline (PBS), permeabilized for 20 min in PBS containing 1\% Triton X-100 (Sigma-Aldrich), and blocked with $10 \%$ horse serum in PBS for $1 \mathrm{~h}$ at room temperature. Sections were then incubated at $4^{\circ}$ $\mathrm{C}$ overnight with primary antibodies against $\gamma \mathrm{H} 2 \mathrm{AX}$ or 53BP1 in combination with antibodies against NeuN or GFAP (Additional file 1: Table S3). Fluorescein isothiocyanate (FITC)-conjugated secondary antibodies (1:75, Vector Laboratories) were used to detect anti- $\gamma \mathrm{H} 2 \mathrm{AX}$, in which case anti-NeuN and anti-GFAP were detected with the Tyramide Signal Amplification (TSA) Direct (Red) system (NEN Life Sciences, Boston, MA). Anti-53BP1 was detected with the tyramide red system, in which case FITC-coupled secondary antibodies were used to detect anti-NeuN and anti GFAP. For the TSA step, horseradish peroxidase (HRP)-coupled secondary antibody was used at 1:500 for $30 \mathrm{~min}$, and TSA working solution was used at 1:100 for $10 \mathrm{~min}$. Negative controls included the omission of each primary antibody. Sections from the mid-frontal cortex and hippocampus (one each per case) were processed simultaneously under the same conditions, and experiments were performed twice. For some sections, Hoechst 33342 was used to stain nuclei. Sections were mounted onto Superfrost Plus slides (Fisher) and covered with ProLong Gold Antifade Mountant (Thermo Fisher Scientific).

Confocal images were acquired with a Radiance 2000 laser scanning confocal microscope (Bio-Rad, Hercules, CA) equipped with an Eclipse E600FN microscope (Nikon, Japan) and a Nikon Plan Apo 60x oil objective (NA 1.4; oil immersion). Two sections were analyzed per case. From each double-labeled section, a total of 10 images $(1024 \times 1024$ pixels, final magnification 630x) were obtained from the mid-frontal cortex (layers 2-3) and hippocampus (CA1, CA3 and dentate gyrus) and analyzed using the ImageJ program [93] as described [87] to determine the proportion of NeuN- or GFAP-positive cells with $\gamma \mathrm{H} 2 \mathrm{AX}$ foci or 53BP1 labeling.

\section{Immunoperoxidase staining to assess AD pathology, calbindin and 53BP1 in human brain sections}

For Cohort 2, free-floating $40-\mu \mathrm{m}$ vibratome sections from the mid-frontal cortex (Brodmann area 46) and anterior hippocampus were washed with TBS, pre-treated in 3\% $\mathrm{H}_{2} \mathrm{O}_{2}$, and blocked with $10 \%$ serum (Vector Laboratories, Burlingame, CA), 3\% bovine serum albumin (Sigma-Aldrich), and $0.2 \%$ gelatin in TBST. Sections were incubated at $4{ }^{\circ} \mathrm{C}$ overnight with the following primary antibodies: anti-A $\beta$, anti-phosphorylated tau, anti-calbindin, or anti-53BP1 (Additional file 1: Table S3). Sections were then incubated in secondary antibodies (1:75, Vector Laboratories), followed by HRP-labeled Avidin D (ABC Elite, Vector Laboratories), and reacted with diaminobenzidine (DAB, $0.2 \mathrm{mg} / \mathrm{ml}$ ) in $50 \mathrm{mM}$ Tris (pH 7.4) 
and $0.001 \% \mathrm{H}_{2} \mathrm{O}_{2}$. Control experiments included replacement of primary antibodies with pre-immune rabbit serum or non-immune IgG1, and preadsorption of the anti-53BP1 antibody at $4{ }^{\circ} \mathrm{C}$ overnight with a 20:1 excess of a synthetic 53BP1 peptide (Abcam, ab98293) designed to block activity of this antibody, followed by centrifugation at $5000 \mathrm{x} \mathrm{g}$ for $10 \mathrm{~min}$ and application of the supernatant to sections.

Immunostained sections were imaged with a BX50 digital microscope (Olympus). A $\beta$ deposits and intraneuronal accumulations of phosphorylated tau were quantified as described [87]. Levels of calbindin and 53BP1 immunoreactivity were quantified using the Image-Pro Plus program (Media Cybernetics, Silver Spring, MD). For each case, 2 sections and 10 digital images per section (at 400x) were analyzed to estimate the average intensity of calbindin immunostaining (corrected optical density) in the dentate gyrus and the average number of 53BP1-immunoreactive cells per $0.1 \mathrm{~mm}^{2}$ in the mid-frontal cortex.

\section{Mice and treatments}

Male and female C57Bl/6 J mice were maintained on a $12 \mathrm{~h} \mathrm{light/dark} \mathrm{cycle.} \mathrm{Experiments} \mathrm{were} \mathrm{conducted} \mathrm{during}$ the light cycle. Mice had free access to food (PicoLab Rodent Diet 20, LabDiet) and water and were housed 2-5 per cage. All studies were approved by the UCSF Institutional Animal Care and Use Committee and were consistent with $\mathrm{NIH}$ guidelines. All mice used were wildtype.

Some mice were exposed once to whole body ionizing radiation ( 4 or $8 \mathrm{~Gy}$ ) from a Mark-I Cesium ${ }^{137}$ source (JL Shepherd and Associates, San Fernando, CA) in a partitioned clear plastic chamber on a rotating platform. The exposure took 1.16-3.32 min and mice were killed between 15 and $120 \mathrm{~min}$ after irradiation as indicated in figure legends.

Unless indicated otherwise, mice were killed following anesthesia with Avertin (tribromoethanol, $250 \mathrm{mg} / \mathrm{kg}$ ) by transcardial perfusion with $0.9 \% \mathrm{NaCl}$. Brains were dissected, divided along the sagittal midline, and hemibrains were frozen on dry ice in cryovials (Wheaton) or fixed in $4 \%$ paraformaldehyde in PBS.

For treatment with kainate alone, kainate was dissolved in $0.9 \%$ saline to a concentration of $4 \mathrm{mg} / \mathrm{ml}$. Some mice received a single intraperitoneal injection of kainate (20 or $30 \mathrm{mg} / \mathrm{kg}$ body weight) or saline. One hour after the injection, mice were anesthetized with Avertin (tribromoethanol, $250 \mathrm{mg} / \mathrm{kg}$ ) and perfused transcardially with $0.9 \% \mathrm{NaCl}$.

For use in combination with irradiation experiments, kainate was dissolved in $0.9 \%$ saline to a concentration of $2 \mathrm{mg} / \mathrm{ml}$. All mice received a single intraperitoneal (i.p.) injection of kainate $(20 \mathrm{mg} / \mathrm{kg}$ body weight) or saline. Some of the mice were then placed into a partitioned clear plastic chamber and received $8 \mathrm{~Gy}$ whole body ionizing radiation $15 \mathrm{~min}$ after the i.p. injection. They were killed $60 \mathrm{~min}$ after the irradiation. Non-irradiated mice were killed $75 \mathrm{~min}$ after the i.p. injection. All mice injected with kainate displayed signs of epileptic activity ranging from rhythmic mouth and facial movements to full motor seizures with loss of postural control.

\section{Immunohistochemical analysis of mouse brain tissues}

Hemibrains were drop-fixed with $4 \%$ paraformaldehyde in PBS for $48 \mathrm{~h}$ at $4{ }^{\circ} \mathrm{C}$, washed in PBS, and infiltrated with $30 \%$ sucrose in PBS until hemibrains sank ( $\geq 12 \mathrm{~h}$ ). Hemibrains were then cut into $30 \mu \mathrm{m}$ sections with a SM200R sliding microtome (Leica). Sections were stored at $-20{ }^{\circ} \mathrm{C}$ in a solution of $40 \%$ PBS, $30 \%$ glycerol and $30 \%$ ethylene glycol until further use.

For fluorescence immunohistochemistry, sections were washed in TBS, permeabilized in TBS with $0.5 \%$ Triton X-100 (Sigma-Aldrich), and incubated for $15 \mathrm{~min}$ at $110^{\circ}$ $\mathrm{C}$ in citrate buffer ( $\mathrm{pH}$ 6.0) for antigen retrieval. After incubating sections for $15 \mathrm{~min}$ in $3 \% \mathrm{H}_{2} \mathrm{O}_{2}$ and $10 \%$ methanol, sections were blocked in 10\% goat serum in TBS for $1 \mathrm{~h}$ and then incubated overnight at $4{ }^{\circ} \mathrm{C}$ with antibodies against parvalbumin, $\gamma \mathrm{H} 2 \mathrm{AX}$, NeuN, or 53BP1 (Additional file 1: Table S3) in 3\% goat serum in TBS with gentle rocking. The next day, sections were rocked at room temperature for $2 \mathrm{~h}$, washed in TBS with $0.1 \%$ Tween and incubated for $2 \mathrm{~h}$ at room temperature with Alexa Fluor secondary antibodies (Thermo Fisher Scientific) at 1:5001:2000 dilution in TBS with 3\% goat serum. Sections were mounted onto glass slides and covered with ProLong Diamond Antifade Mountant (Thermo Fisher Scientific).

Confocal images were acquired from hippocampal CA1 or dentate gyrus with an LSM 880 confocal laser scanning microscope (Zeiss) and a 20x objective lens (NA 0.8). Z-stack images were taken with sequential acquisition settings at pixel size of $1.66 \mu \mathrm{m}$ for low-magnification images and 0.21 or $0.41 \mu \mathrm{m}$ for high-magnification images. Maximum intensity projections were created for all images. Images of the entire dentate gyrus were stitched together using ZEN software (Zeiss). Images acquired from two coronal sections per mouse were analyzed. Briefly, the dentate gyrus and a background area containing no cells were manually traced as regions of interest. After subtracting the $\gamma \mathrm{H} 2 \mathrm{AX}$ fluorescence intensity of the background region from the fluorescence intensity in the dentate gyrus, the fluorescence intensity in kainate-injected mice was normalized to that in saline-injected mice.

\section{DI-PLA on mouse brain sections}

Snap-frozen mouse hemibrains were embedded in O.C.T. compound (Tissue-Tek), cryosectioned at $10 \mu \mathrm{m}$, mounted on Superfrost Plus Gold slides (Thermo Fisher Scientific), and stored at $-80^{\circ} \mathrm{C}$ until use. Using the Duolink PLA 
Orange detection reagent (Sigma-Aldrich) per manufacturer's instructions, the DI-PLA was then carried out as described [23] with the following modifications. Before blunting DSB ends, endogenous biotin was blocked with a biotin blocking kit (Molecular Probes) per manufacturer's instructions. Ligation of the biotinylated linker was carried out for $1 \mathrm{~h}$ at room temperature as opposed to overnight at $16^{\circ} \mathrm{C}$. Sections were incubated in anti- $\gamma \mathrm{H} 2 \mathrm{AX}$ and anti-biotin antibodies in PBS with $0.1 \%$ Tween and $5 \%$ goat serum overnight at $4{ }^{\circ} \mathrm{C}$. After completion of PLA chemistry per manufacturer's instructions, sections were incubated with anti-NeuN antibody in PBS with $0.1 \%$ Tween and $5 \%$ goat serum for $0.5-1.0 \mathrm{~h}$ at room temperature. Sections were then incubated with Alexa Fluor-conjugated secondary antibodies (Thermo Fisher Scientific; $1: 1000$ ) in PBS with $0.1 \%$ Tween and $5 \%$ goat serum for $1 \mathrm{~h}$ at room temperature to visualize NeuN in addition to the PLA signal. Sections were then washed in PBS with $0.1 \%$ Tween and then with PLA wash buffers A and $B$, prepared per manufacturer's protocols. After completion of the DI-PLA protocol, sections were allowed to air dry at room temperature while protected from light. They were then covered with ProLong Diamond Antifade Mountant (Thermo Fisher Scientific).

Slides were imaged with a Zeiss LSM 880 confocal microscope and a $20 \mathrm{X}$ objective (NA 0.8). Z-stack images were taken with sequential acquisition settings at pixel sizes of $0.15-0.41 \mu \mathrm{m}$. Maximum intensity projections were created for all images. As specified in figure legends, 3-4 images of the somatosensory cortex or dentate gyrus were obtained from each of two sections per mouse. For negative control sections, 2-3 images were obtained from a single section per mouse.

Images were analyzed using ImageJ [93] and a macro developed in-house. Briefly, maximum intensity projections were background subtracted, the NeuN channel was then thresholded and smoothed, and neuronal nuclei were identified and assigned as regions of interest (ROI) using the "analyze particles" function. The "find maxima" function was then used on the corresponding DI-PLA channel to automatically count the number of DI-PLA foci in the defined ROI. For cortical sections, the number of DI-PLA foci per neuron was calculated; for dentate gyrus sections, the number of DI-PLA foci per $100 \mu \mathrm{m}^{2}$ neuronal area was calculated. A background noise tolerance was set by the experimenter to ensure only DI-PLA foci were detected as "maxima." For any given experiment, all user-defined variables were kept constant across all images. Calculations were processed using Python scripts developed in-house.

\section{Generation, treatment and immunocytochemistry of primary neuronal cultures}

Primary hippocampal neuronal cultures were established from individual day- $0 \mathrm{C} 57 \mathrm{Bl} / 6 \mathrm{~J}$ mouse pups as described
[75]. Cells were cultured on poly-D-lysine-coated 96-well plates (Greiner; 20 wells/pup) in $100 \mu \mathrm{l}$ Neurobasal medium (Thermo Fisher Scientific) supplemented with 2\% B27 (Thermo Fisher Scientific), penicillin/streptomycin, and 1x GlutaMAX Supplement (Thermo Fisher Scientific). On days in vitro (DIV) $7,100 \mu \mathrm{l}$ of fresh medium was added to the conditioned medium in each well.

At DIV 14, cultures were pretreated for $1 \mathrm{~h}$ with fully conditioned medium containing vehicle or $1 \mu \mathrm{M}$ tetrodotoxin (TTX) and then treated for $1 \mathrm{~h}$ with the same conditioned medium containing vehicle or bicuculline $(10 \mu \mathrm{M})$. Cultures were then fixed with $4 \%$ paraformaldehyde in PBS for 15 min.

Fixed neuronal cultures were permeabilized in PBS with $0.2 \%$ Triton X-100 (Sigma-Aldrich) for $5 \mathrm{~min}$, blocked in $10 \%$ goat serum in PBS for $1 \mathrm{~h}$, and incubated with anti- $\gamma \mathrm{H} 2 \mathrm{AX}(1: 1000)$ and anti-NeuN (1:4000) antibodies in $2 \%$ goat serum for $1.5 \mathrm{~h}$ at room temperature. After 5 brief washes in PBS, cultures were incubated with Alexa-Fluor conjugated secondary antibodies (1:2000, Thermo Fisher Scientific) and Hoechst $33342(5 \mu \mathrm{M})$ in PBS with $2 \%$ goat serum for $1 \mathrm{~h}$ at room temperature. After 5 more brief washes in PBS, cultures were kept in $\mathrm{PBS}$ at $4{ }^{\circ} \mathrm{C}$ until imaging.

Immunostained cultures were imaged with a high-content ArrayScan system (Thermo Fisher Scientific) and a $40 x$ objective, yielding $1024 \times 1024$ pixels per image. For each well, 15-20 images were obtained from different areas. For the $\gamma \mathrm{H} 2 \mathrm{AX}$ channel, maximum intensity projections were calculated from 4 images taken at $1 \mu \mathrm{m}$ intervals along the $\mathrm{z}$-axis ( 2 above and 2 below the focal plane). For all other channels, a single z-plane was imaged. ArrayScan software was used for image analysis. Briefly, the Hoechst 33342 channel was used to define nuclei as regions of interest and intensity values were calculated within those nuclei for each channel. An average nuclear $\gamma \mathrm{H} 2 \mathrm{AX}$ intensity was calculated for NeuN-positive cells. The median $\gamma \mathrm{H} 2 \mathrm{AX}$ intensity for all neurons in a well was calculated. For each independent neuronal culture, all wells of comparable conditions were treated as technical replicates. The means of technical replicates were then calculated and independent cultures were used as biological replicates for statistical analyses.

\section{Comet assay (single cell gel electrophoresis)}

Primary hippocampal neuronal cultures were treated with bicuculline $(5 \mu \mathrm{M})$, etoposide $(10 \mu \mathrm{M})$ or vehicle for $1 \mathrm{~h}$ at DIV 14. Cultures were rinsed once with cold $\mathrm{Ca}^{2+}$ and $\mathrm{Mg}^{2+}$-free PBS, collected by gentle scraping, spun down, and mixed with low-melting point agarose (Trevigen). $50 \mu \mathrm{l}$ of the mixture was applied onto each CometSlide (Trevigen) and allowed to solidify at $4{ }^{\circ} \mathrm{C}$ for 
$30 \mathrm{~min}$. Lysis and comet assay were performed according to instructions provided with the CometAssay kit (Trevigen) with minor modifications. Briefly, cells were lysed for $30 \mathrm{~min}$ at $4{ }^{\circ} \mathrm{C}$, immersed in $1 \mathrm{x}$ TBE buffer for $15 \mathrm{~min}$, and electrophoresis was performed at neutral $\mathrm{pH}$ at $1 \mathrm{~V} / \mathrm{cm}$ (measured electrode to electrode) for $30 \mathrm{~min}$. Slides were immersed in $\mathrm{dH}_{2} \mathrm{O}$ for $5 \mathrm{~min}, 70 \%$ ethanol for $5 \mathrm{~min}$, and dried at room temperature overnight. Samples were then stained with SYBR Green and imaged with a Zeiss LSM 880 microscope and a Fluar $5 \mathrm{X}$ objective (NA 0.25). DNA damage was assessed by measuring comet tail length using OpenComet software (v1.3.1). Experiments were performed in three independent cultures established from different mice. A total of 150-200 nuclei were measured for each mouse and treatment condition.

\section{Statistical analysis}

Biological units were randomized during assays, imaging and analyses. All images for a given experiment were acquired using the same acquisition parameters. Wherever possible, investigators were blinded during image acquisition and quantitations to clinicopathologic group of humans and to treatment of mice. After acquisition, images for a given experiment were randomized and renamed using a custom MATLAB (MathWorks) script. Data were formatted and processed in Excel (Microsoft), MATLAB (MathWorks) or Python. Statistical analyses were carried out in Prism (GraphPad). For hypothesis testing, data were first tested for normality using the Shapiro-Wilk test. For normally distributed data, unpaired two-tailed Student's t-tests were used to compare two groups, and one-way or two-way ANOVA with Holm-Sidak post-hoc tests to compare three or more groups. For data that were not normally distributed, we used the Mann-Whitney U test to compare two groups and the Kruskal-Wallis test and Holm-Sidak post-hoc tests to compare three or more groups. The null hypothesis postulated no difference between groups and was rejected at $P<0.05$. Quantitative data are presented as means \pm SEM.

\section{Results}

$A D$ and $\mathrm{MCl}$ are associated with an accumulation of $\mathrm{pH} 2 \mathrm{AX}$ foci in nuclei of neurons and astrocytes

To explore whether $A D$ is associated with evidence for excessive neuronal DSBs, we first obtained postmortem brain tissues from a relatively small pilot cohort (Additional file 1: Table S1) and co-labeled sections of the orbitofrontal cortex with antibodies against $\gamma \mathrm{H} 2 \mathrm{AX}$ and the postmitotic neuronal marker NeuN. In this cohort, we detected a trend towards increased proportions of neurons with $\gamma \mathrm{H} 2 \mathrm{AX}$ foci and an increased number of $\gamma \mathrm{H} 2 \mathrm{AX}$ foci per neuron in AD and mild cognitive impairment (MCI) cases as compared to cases without cognitive impairment (Additional file 1: Figures S1 and S2a). Consistent with a previous report [76], several AD cases and one MCI case had high levels of $\gamma \mathrm{H} 2 \mathrm{AX}$ immunoreactivity in a proportion of NeuN-negative cells (Additional file 1: Figure S3 and data not shown), whereas the control cases did not. However, this non-neuronal $\gamma \mathrm{H} 2 \mathrm{AX}$ immunostaining was pan-nuclear rather than focal and, thus, may not represent DSBs (see below).

Based on these preliminary findings, we extended our analysis to an independent, larger cohort of human cases (Additional file 1: Table S2). We found that both AD and MCI cases had twice as many neurons with $\gamma \mathrm{H} 2 \mathrm{AX}$ foci in the frontal cortex than cognitively unimpaired controls (Fig. 1a, b). The number of $\gamma \mathrm{H} 2 \mathrm{AX}$ foci per neuron was also higher in $\mathrm{AD}$ and $\mathrm{MCI}$ cases than in controls (Additional file 1: Figure S2b). Similar changes were observed in the hippocampal CA1 region (Additional file 1: Figure S4a).

$\mathrm{AD}$ and MCI cases showed comparable levels of neurons with DSBs (Fig. 1a, b, Additional file 1: Figure S4a), even though the accumulation of $A \beta$ and phosphorylated tau was much more extensive in $\mathrm{AD}$ than MCI brains (Additional file 1: Figure S5). Interestingly, AD and MCI cases showed comparable levels of calbindin depletion in the dentate gyrus (Additional file 1: Figure S5), an abnormality that likely reflects aberrant neural network activity [81, 82], which has been implicated in the generation of neuronal DSBs $[64,106]$.

In Cohort 2, we also examined GFAP-positive astrocytes in greater detail. Compared to controls, AD and MCI cases had an increased proportion of GFAP-positive astrocytes with $\gamma \mathrm{H} 2 \mathrm{AX}$ foci in the frontal cortex (Fig. 1c, d) and CA1 region (Additional file 1: Figure S4b). Thus, our data suggest that AD causes an accumulation of DSBs in both neurons and astrocytes and that this process begins at relatively early stages of disease progression.

\section{$A D$ and $M C l$ are associated with neuronal increases and astroglial decreases in pan-nuclear 53BP1 staining}

Eliciting neuronal DSBs by irradiation or other means in mice leads to the formation of distinct $\gamma \mathrm{H} 2 \mathrm{AX}$ foci in brain cells that are co-labeled by antibodies to 53BP1 (Additional file 1: Figure S6 and ref. [106]), a protein that is rapidly recruited to DSBs and has many putative functions, including the promotion of DSB repair by the non-homologous end-joining pathway [84]. To further support our conclusion that the $\gamma \mathrm{H} 2 \mathrm{AX}$ foci we detected in $\mathrm{AD}$ and $\mathrm{MCI}$ cases represent genuine DSBs, we immunostained brain sections from Cohort 2 for this additional DSB marker. AD and MCI cases showed marked and comparable increases in the proportion of neurons with nuclear 53BP1 staining in the frontal cortex 


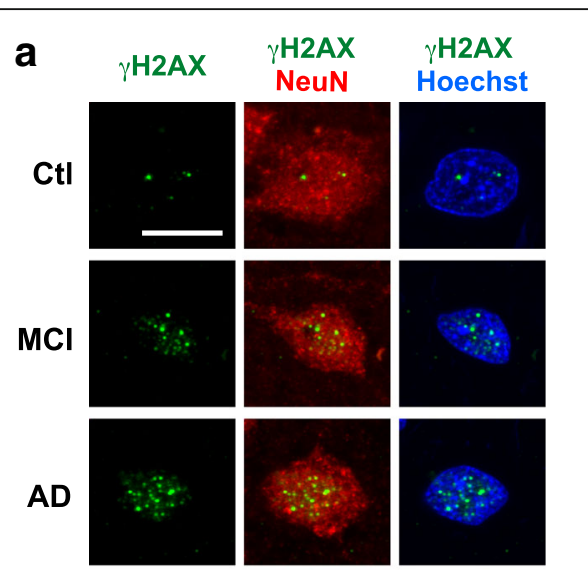

b
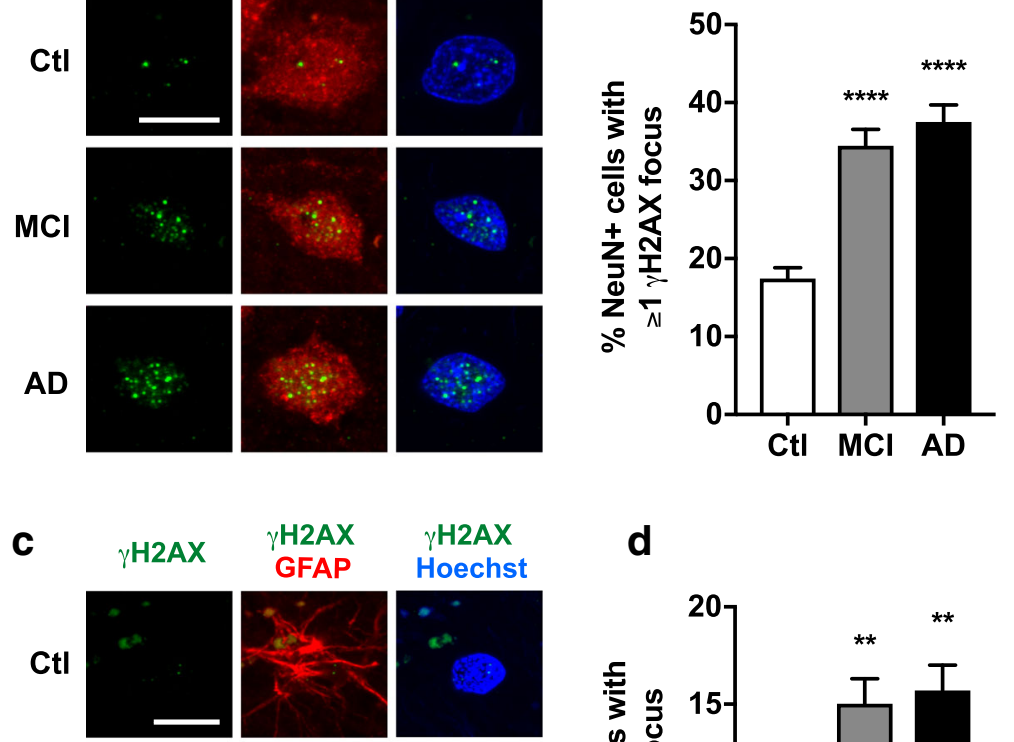

$\gamma \mathrm{H} 2 \mathrm{AX}$

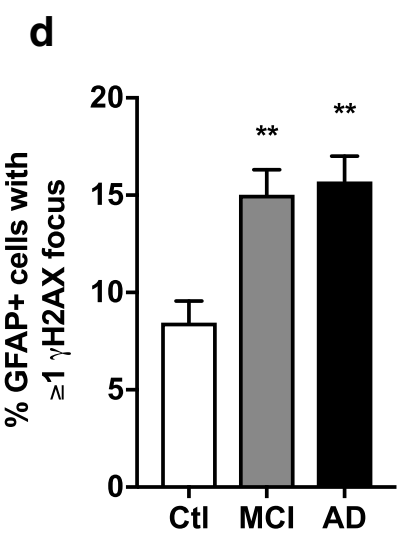

Fig. 1 Increased proportion of neurons and astrocytes with $\mathrm{YH} 2 \mathrm{AX}$ foci in frontal cortex of cases with $\mathrm{MCl}$ or $\mathrm{AD}$. Frontal cortex sections from cognitively unimpaired controls $(\mathrm{Ctl})$ and from $\mathrm{MCl}$ and $\mathrm{AD}$ cases were co-labeled for $\mathrm{\gamma H} 2 \mathrm{AX}$ (green) and for NeuN (red) (a, b) or the astroglial marker GFAP (red) (c, d). Nuclei were stained with Hoechst 33342 (blue). a Representative confocal images of neuronal $\gamma \mathrm{H} 2 \mathrm{AX}$ staining. b Proportion (\%) of neurons with at least one $\mathrm{\gamma H} 2 \mathrm{AX}$ focus. $\mathbf{c}$ Representative confocal images of astroglial $\gamma \mathrm{H} 2 \mathrm{AX}$ staining. $\mathbf{d}$ Proportion (\%) of astrocytes with at least one $\mathrm{yH} 2 \mathrm{AX}$ focus. $n=8 \mathrm{Ctl}, 7 \mathrm{MCl}$, and $8 \mathrm{AD}$ cases from Cohort $2 .{ }^{* *} p<0.01,{ }^{* * * *} p<0.0001 \mathrm{vs}$. Ctl by one-way ANOVA and Holm-Sidak test. Scale bars: $10 \mu \mathrm{m}$. Bar graphs represent means \pm SEM

and CA1 region (Fig. 2a, b, Additional file 1: Figure S4c). However, in most neurons this 53BP1 staining was diffuse and pan-nuclear rather than focal or punctate (Fig. 2a), similar to what others have observed in neurons of deep cerebellar nuclei from AD cases [10]. To ensure the target specificity of this staining, we tested an independent 53BP1 antibody. It yielded a similar staining pattern, which was eliminated by pre-adsorption of the antibody with a peptide representing the 53BP1 immunogen (Additional file 1: Figure S7).

To investigate whether the increased neuronal 53BP1 staining in $\mathrm{AD}$ and $\mathrm{MCI}$ cases might have emerged postmortem, we elicited neuronal DSBs in mice by irradiation and drop-fixed their brains in 10\% neutral buffered formalin for $48 \mathrm{~h}$ either immediately after sacrifice or after different postmortem intervals (PMI). Even after a PMI of $9 \mathrm{~h}$, irradiated mice showed marked increases in crisp 53BP1 foci, which co-localized with $\gamma \mathrm{H} 2 \mathrm{AX}$, rather than pan-nuclear increases in diffuse 53BP1 staining
(Additional file 1: Figure S8). These results make it unlikely that the increases in neuronal 53BP1 labeling we and others [10] have detected in humans with $\mathrm{AD}$ or MCI represent a postmortem artifact.

Surprisingly, AD and MCI cases had a lower proportion of GFAP-positive astrocytes with pan-nuclear 53BP1 staining than controls (Fig. 2c, d, Additional file 1: Figure S4d). Although the processes that cause $\mathrm{AD}$-associated changes in 53BP1 expression remain to be determined, our results make it likely that they affect neurons and astrocytes differentially.

\section{Pan-nuclear H2AX phosphorylation in neurons can be} caused by increases in neuronal activity but is unlikely to represent DSBs

As described above, focal $\gamma \mathrm{H} 2 \mathrm{AX}$ immunoreactivity is a well-established marked of DSBs. While measuring this marker, we noticed that $\gamma \mathrm{H} 2 \mathrm{AX}$ immunostaining labels the nuclei of some neurons diffusely, in humans as well 

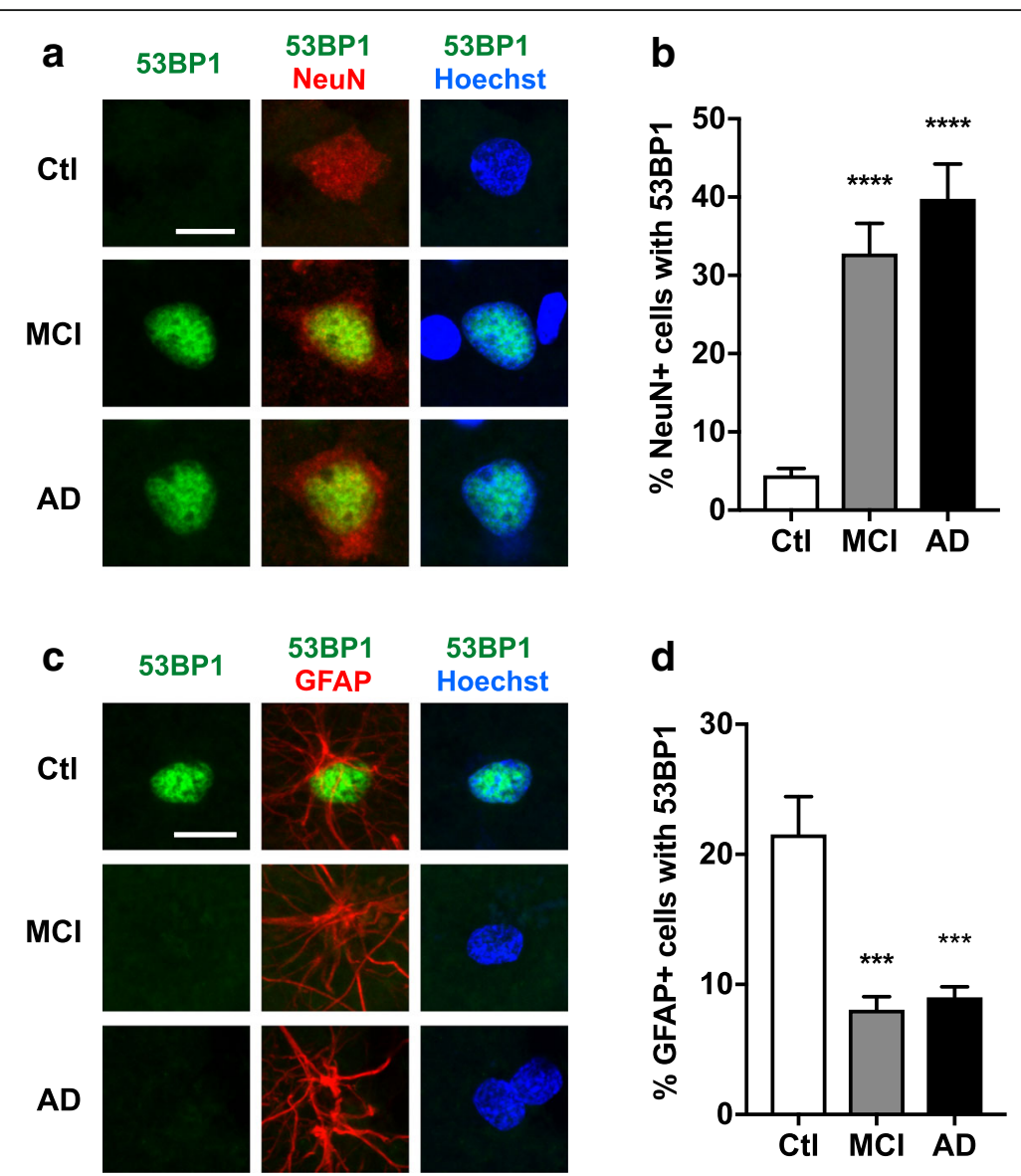

Fig. 2 Pan-nuclear 53BP1 staining is increased in neurons and decreased in astrocytes in frontal cortex of $M C l$ and $A D$ cases. Frontal cortex sections from cognitively unimpaired controls (Ctl) and from MCl and AD cases were double-labeled for 53BP1 (green) and for NeuN (red) (a, b) or the astroglial marker GFAP (red) (c, d). Nuclei were stained with Hoechst 33342 (blue). a Representative confocal images of neuronal 53BP1 staining. b Proportion (\%) of neurons with pan-nuclear 53BP1 staining. c Representative confocal images of astroglial 53BP1 staining. d Proportion (\%) of astrocytes with pan-nuclear 53BP1 staining. $n=8 \mathrm{Ctl}, 7 \mathrm{MCl}$, and $8 \mathrm{AD}$ cases from Cohort $2 .{ }^{* * *} p<0.001,{ }^{* * *} p<0.0001$ vs. Ctl by one-way ANOVA and Holm-Sidak test. Scale bars: $10 \mu \mathrm{m}$. Bar graphs represent means \pm SEM

as mice (Fig. 3). In wildtype mice that were not exposed to any experimental manipulation before death, a large proportion of specific neuronal populations showed prominent pan-nuclear $\gamma \mathrm{H} 2 \mathrm{AX}$ staining, for example, $\geq 30 \%$ of parvalbumin-positive interneurons in CA1 (Fig. $3 \mathrm{~b})$. These findings raise the intriguing possibility that focal and pan-nuclear patterns of H2AX phosphorylation have different causes and consequences.

Because parvalbumin-positive interneurons are among the fastest spiking neurons in the brain [32], we wondered whether neuronal activity itself could increase pan-nuclear $\gamma \mathrm{H} 2 \mathrm{AX}$ staining. To test this hypothesis, we injected mice with the glutamate receptor agonist kainate to induce epileptic activity. Within one hour after mice received an intraperitoneal injection of kainate $(20-30 \mathrm{mg} / \mathrm{kg}$ body weight), they all showed evidence of seizure activity (data not shown). Compared to saline-injected controls, kainate-injected mice showed a marked increase in pan-nuclear neuronal $\gamma \mathrm{H} 2 \mathrm{AX}$ staining in the dentate gyrus (Fig. 4a, b).

To further assess the relationship between neuronal activity and pan-nuclear $\gamma \mathrm{H} 2 \mathrm{AX}$ staining, we increased the activity of mouse neurons by treating primary cultures with the $\mathrm{GABA}_{\mathrm{A}}$ receptor antagonist, bicuculline. This treatment was well tolerated and did not cause overt toxicity at the doses used here (data not shown). One hour after bicuculline treatment, NeuN-positive neurons showed a robust increase in $\gamma \mathrm{H} 2 \mathrm{AX}$ staining, which was pan-nuclear rather than focal (Fig. 4c, d). Pre-treatment of neuronal cultures with the sodium channel antagonist tetrodotoxin (TTX) abolished the bicuculline-induced increases in $\gamma \mathrm{H} 2 \mathrm{AX}$ staining, confirming that they were indeed activity-dependent (Fig. 4c, d). Taken together, these results suggest that high levels of neuronal activity promote pan-nuclear H2AX phosphorylation in vitro and in vivo, possibly without causing the formation of DSBs. 

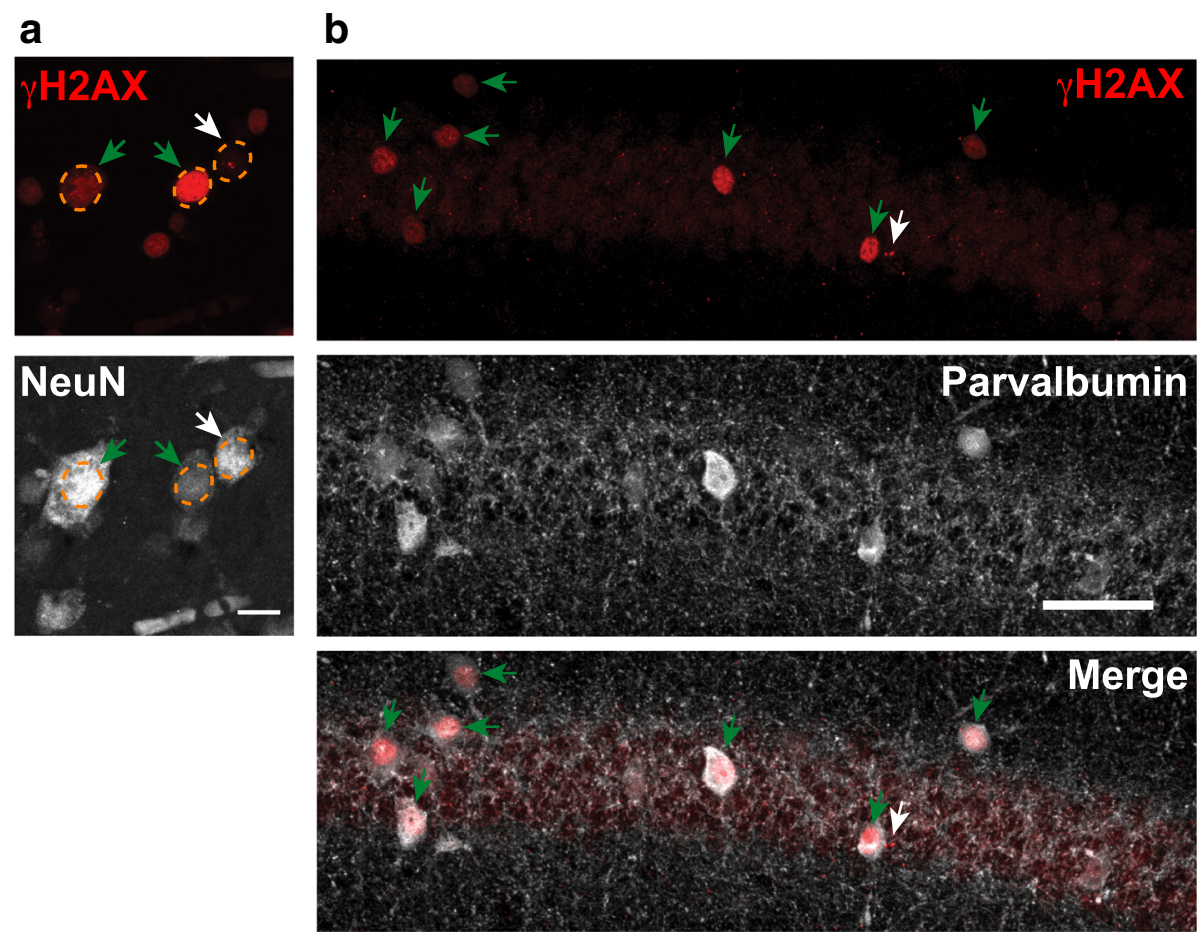

Fig. 3 Pan-nuclear H2AX phosphorylation in neurons of humans and mice. a Representative confocal microscopic images of sections from the orbitofrontal cortex of an AD case from Cohort 1. Sections were immunostained for $\mathrm{yH} 2 \mathrm{AX}$ (red) and NeuN (grey). Orange circles outline nuclei. Two distinct patterns of Y H2AX immunoreactivity were observed: foci (white arrows) and pan-nuclear (green arrows). Scale bar: $10 \mu \mathrm{m}$. b Representative confocal images of sections from the CA1 region of a mouse. Sections were immunostained for $\mathrm{\gamma H} 2 \mathrm{AX}$ (red) and parvalbumin (grey). Green arrows highlight the large proportion of parvalbumin-positive interneurons showing pan-nuclear $\mathrm{H} 2 \mathrm{AX}$ labeling under physiological conditions. Scale bar: $50 \mu \mathrm{m}$

Comet assay and DI-PLA reveal no evidence for DSBs in neurons with pan-nuclear $\mathrm{H} 2 \mathrm{AX}$ phosphorylation

To determine whether pan-nuclear H2AX phosphorylation is associated with DSBs, we first performed the comet assay in primary hippocampal cultures. Performed at neutral $\mathrm{pH}$, this assay mainly detects DSBs, the extent of which is reflected by the length of comet tails that emerge from cell nuclei upon electrophoresis [78]. The mean comet tail length from bicuculline-treated samples was not significantly different from mock-treated samples (Fig. 5a, b), although bicuculline treatment induced pannuclear $\gamma \mathrm{H} 2 \mathrm{AX}$ staining (Fig. 5c). Positive control samples treated with the genotoxic agent etoposide showed increased comet tail length and $\gamma \mathrm{H} 2 \mathrm{AX}$ foci (Fig. 5). These results further support the notion that pan-nuclear $\gamma \mathrm{H} 2 \mathrm{AX}$ formation can occur in the absence of DSBs.

The neutral comet assay does not determine the specific cell types that harbor DSBs. To address this shortcoming and to further differentiate between DSBs and pan-nuclear $\gamma \mathrm{H} 2 \mathrm{AX}$ formation, we used the recently developed DNA damage in situ ligation followed by proximity ligation assay (DI-PLA) [23]. This assay (Fig. 6a) builds on the original findings that double stranded linkers can be specifically ligated to free DSBs in situ [29] and that when such linkers are biotinylated, DSB ends can be purified on streptavidin beads [14]. To identify bona fide DSBs, Galbiati and colleagues combined this biotinylated DSB linker strategy with a proximity ligation assay that allows for the visualization of chromatin sites at which free DSB ends are located in close proximity to $\gamma \mathrm{H} 2 \mathrm{AX}$ [23].

We first confirmed that the DI-PLA readily detects DSBs in the brains of mice that were exposed to whole-body ionizing radiation (Fig. 6b). Following this treatment, DI-PLA signals in neurons increased, peaking at approximately $1 \mathrm{~h}$ after irradiation, and then decreased, most likely as the result of DSB repair (Fig. 6c). Negative controls included the omission of the biotinylated linker and of primary or secondary antibodies (Fig. 6c).

To exclude the possibility that pan-nuclear $\gamma \mathrm{H} 2 \mathrm{AX}$ staining simply obscures the presence of $\gamma \mathrm{H} 2 \mathrm{AX}$ foci representing DSBs, we designed the experiment outlined in Fig. 7a. To increase the number of neurons with pan-nuclear $\gamma \mathrm{H} 2 \mathrm{AX}$ staining, mice received an intraperitoneal injection of kainate $(20 \mathrm{mg} / \mathrm{kg})$, or saline as a negative control. To cause DSBs, roughly half of the mice received $8 \mathrm{~Gy}$ of ionizing whole-body irradiation shortly after the injection of kainate or saline. All mice were then analyzed by immunohistochemistry and DI-PLA. Kainate treatment increased the proportion of neurons with pan-nuclear $\gamma \mathrm{H} 2 \mathrm{AX}$ staining in the dentate gyrus but did 


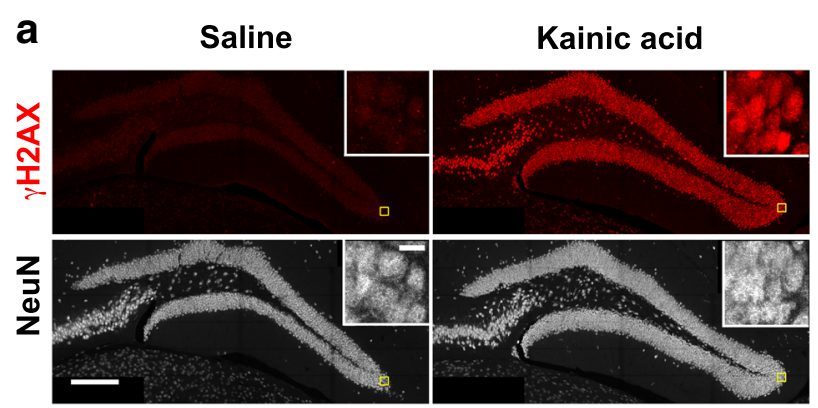

C
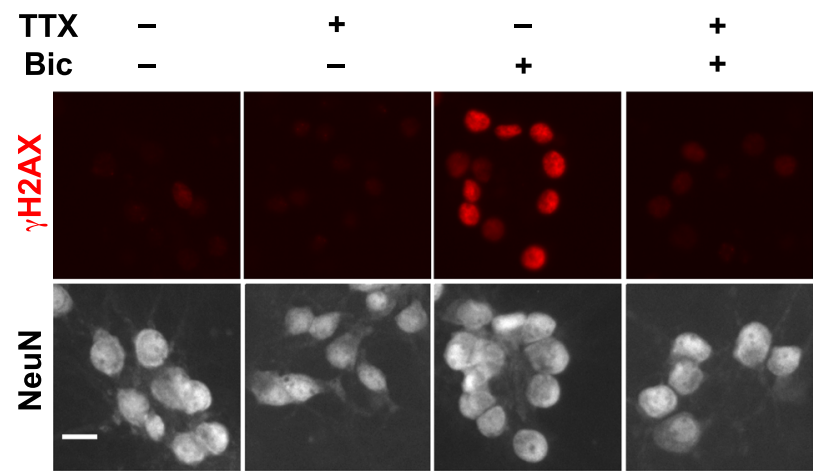

b

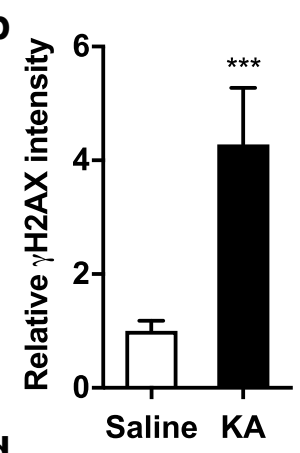

d

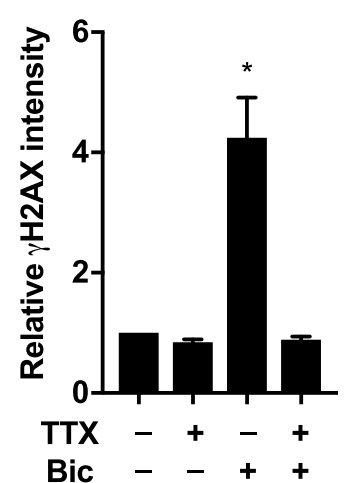

Fig. 4 Increased neuronal activity causes pan-nuclear neuronal $\mathrm{yH} 2 \mathrm{AX}$ labeling in vivo and in vitro. a, b Mice were analyzed $1 \mathrm{~h}$ after they received an intraperitoneal injection of kainate (KA, 20 or $30 \mathrm{mg} / \mathrm{kg}$ ) or vehicle (saline) at 4-6 months of age. a Representative confocal microscopic images of dentate gyrus sections co-labeled for $\mathrm{\gamma H} 2 \mathrm{AX}$ (red) and NeuN (grey). Insets show higher magnification views of the areas outlined by yellow squares. Note the pan-nuclear pattern of the $\mathrm{YH} 2 \mathrm{AX}$ labeling. Scale bars: $200 \mu \mathrm{m} ; 10 \mu \mathrm{m}$ (insets). b Quantitation of $\mathrm{\gamma H} 2 \mathrm{AX}$ immunofluorescence intensity in the dentate gyrus. Mean levels in saline-treated mice were arbitrarily defined as 1.0. $n=9$ mice per group (pooled from 3 independent experiments). ${ }^{* * *} p<0.001$ by Mann-Whitney test. $\mathbf{c}$, $\mathbf{d}$ Primary hippocampal neuronal cultures from mice were pretreated for $1 \mathrm{~h}$ with vehicle or tetrodotoxin $(T T X, 1 \mu \mathrm{M})$ on DIV 14. Vehicle or bicuculline (Bic, $10 \mu \mathrm{M})$ was then added to the medium and cultures were incubated for $1 \mathrm{~h}$. c Representative widefield images of neuronal cultures co-labeled for $\mathrm{\gamma H} 2 \mathrm{AX}$ (red) and NeuN (grey). Scale bar: $10 \mu \mathrm{m}$. d Quantitation of neuronal $\mathrm{\gamma H} 2 \mathrm{AX}$ immunofluorescence intensity. For each culture, the mean levels in different wells of saline-treated cultures were arbitrarily defined as 1.0. $n=4$ independent cultures from different mice per condition. ${ }^{*} p<0.05$ vs. mean of 1.0 (control) by one sample t-test. Bars represent means \pm SEM

not cause $\gamma \mathrm{H} 2 \mathrm{AX}$ foci, unless mice were also irradiated (Fig. 7b, c). The dose of irradiation used here caused many neuronal DSBs, which were readily detectable by $\gamma \mathrm{H} 2 \mathrm{AX}$ staining and by DI-PLA independent of whether neurons had kainate-induced increases in pan-nuclear $\gamma \mathrm{H} 2 \mathrm{AX}$ staining or not (Fig. 7d, e). Thus, in the absence of focal $\gamma \mathrm{H} 2 \mathrm{AX}$ staining, pan-nuclear $\gamma \mathrm{H} 2 \mathrm{AX}$ staining should not be interpreted as evidence for DSBs and may reflect increased levels of neuronal activity.

Lastly, we attempted to use the DI-PLA for the detection of DSBs in human postmortem tissues. However, we observed substantial signal variations when we analyzed sections from the same cases on different occasions (data not shown). We did not find such variations in mice, in which the DI-PLA yielded reliable results even when we simulated human postmortem conditions (Additional file 1: Figure S9), suggesting that the difference may be due to premortem factors or other variables.

\section{Discussion}

Our results suggest that AD causes neuronal accumulation of DSBs even at relatively early stages of the illness. Because unrepaired DSBs can lead to cell death $[4,120]$, neuronal DSB accumulation may contribute to neurodegeneration. DSBs can also cause changes in transcription from gene promoters located near break sites $[36,47,85,96]$, which could lead to changes in neuronal and synaptic functions. Recent evidence suggests that neuronal DSB formation could also provide entry points for the retro-insertion of genomic complementary DNAs and give rise to mosaic mutations of the $A P P$ gene in AD [49]. DSB-related changes in gene expression may explain, at least in part, why some brain regions that are relatively resistant to neuronal loss in AD—for example, the dentate gyrus—still show molecular and radiological alterations suggestive of major dysfunction $[1,2,13,81,103]$. 
a

Control

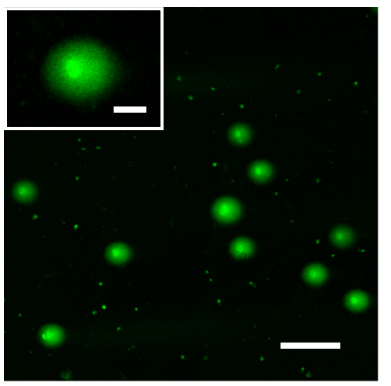

b

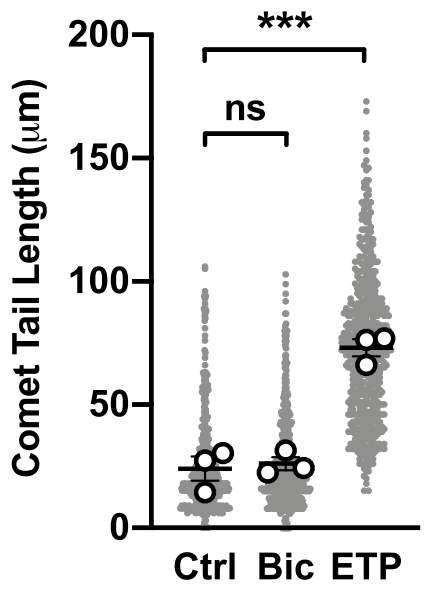

Bicuculline

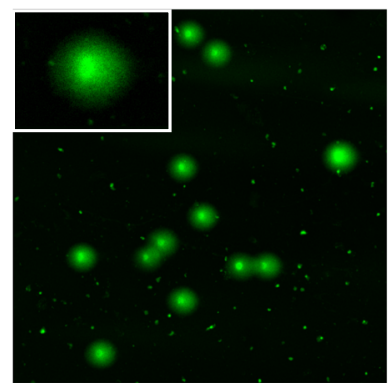

C
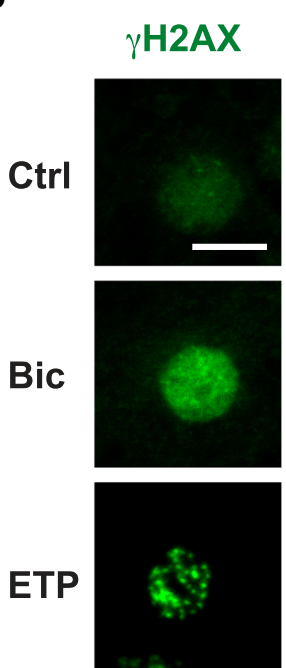

Etoposide

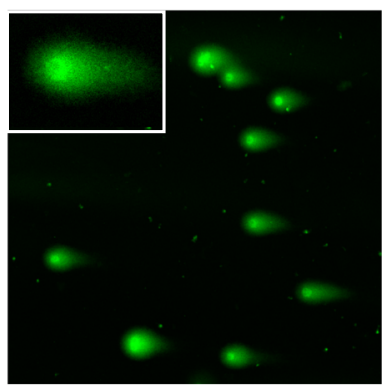

$\gamma \mathrm{H} 2 \mathrm{AX}$

$\gamma \mathrm{H} 2 \mathrm{AX}$

NeuN Hoechst
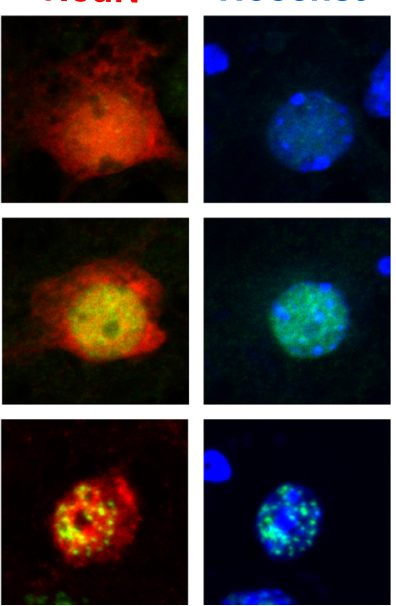

Fig. 5 Neutral comet assay detects no DSBs in primary cultures with elevated neuronal activity and pan-nuclear $\gamma H 2 A X$ elevation. a-c Cultures of primary hippocampal mouse neurons were assessed for DSB levels by the neutral comet assay (a, b) or immunocytochemistry (c). Cells were treated with vehicle (Ctrl), $10 \mu \mathrm{M}$ bicuculline (Bic) or $5 \mu \mathrm{M}$ etoposide (ETP) for $1 \mathrm{~h}$ before harvesting. a Representative images of cell nuclei stained with SYBR Green after electrophoresis at neutral pH. Insets show higher magnification views. Scale bar: $100 \mu \mathrm{m} ; 20 \mu \mathrm{m}$ (insets). b Quantitation of comet tail lengths. A total of 150-200 nuclei were measured for each mouse and condition. $n=3$ cultures/mice per condition. Circles indicate mean values for each mouse; grey dots indicate individual nuclei. ${ }^{* *} p<0.001$ by one-way ANOVA and Holm-Sidak test. ns, not significant. c Representative confocal images of cultured neurons exposed to the indicated treatments. Cells were co-labeled for $y \mathrm{H} 2 \mathrm{AX}$ (green), NeuN (red), and Hoechst 33342 (blue). Scale bar: $10 \mu \mathrm{m}$

In dividing cell lines, some experimental conditions can cause $\gamma \mathrm{H} 2 \mathrm{AX}$ foci without causing DSBs [43, 73, 88]. However, it is unclear how these findings relate to DNA damage responses in the brain. In vivo, $\gamma \mathrm{H} 2 \mathrm{AX}$ foci appear to be reliable indicators of true DSBs [54]. By immunostaining for $\gamma \mathrm{H} 2 \mathrm{AX}$ foci in postmortem brain sections, we showed that neuronal DSBs accumulate in $\mathrm{MCI}$ and $\mathrm{AD}$ to a greater extent than in cognitively normal controls.

How does AD increase DSBs in neurons? During normal aging, oxidative DNA damage accumulates in the promoters of genes involved in learning and memory and in neuronal survival [62]. AD further increases oxidative damage in neurons $[8,59,60,69]$. Oxidative damage can result in DSBs, particularly when multiple oxidative lesions occur close to one another [94, 97].
Therefore, excessive production and/or reduced inactivation of free radicals represent plausible mechanisms for the accumulation of neuronal DSBs in AD. Other lines of evidence suggest that aberrant neuronal activity can increase neuronal DSBs independent of oxidative stress [106] and that increased or excessive stimulation of neuronal glutamate receptors can lead to DSB formation within the promoters of early-response genes [64]. In light of these studies, chronic network hyperexcitability, which is prevalent in $\mathrm{AD}[30,48,82,111,112]$, might also contribute to the accumulation of neuronal DSBs. In line with this notion, we found reduced neuronal levels of calbindin in the dentate gyrus of MCI and AD cases, a reliable indicator of chronic network hyperexcitability and excessive calcium influx $[34,72,81]$. However, acute 


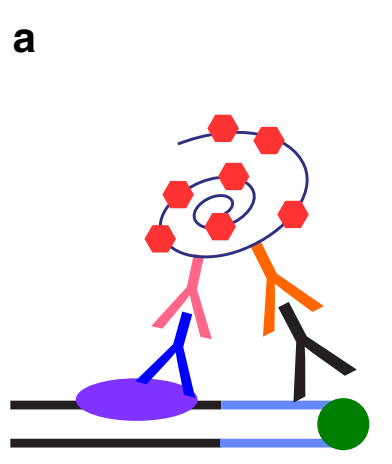

b

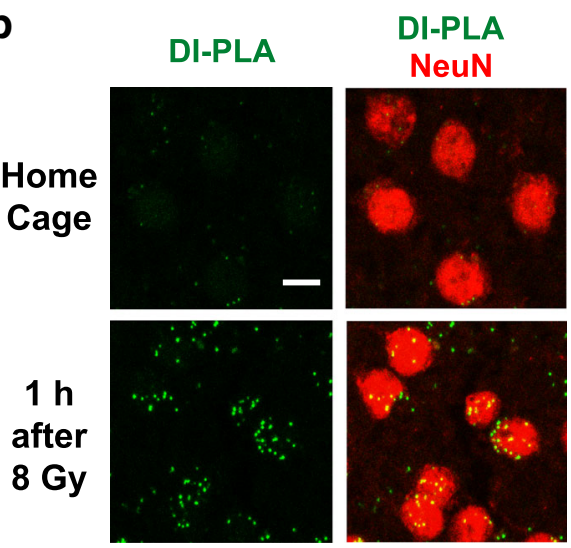

C

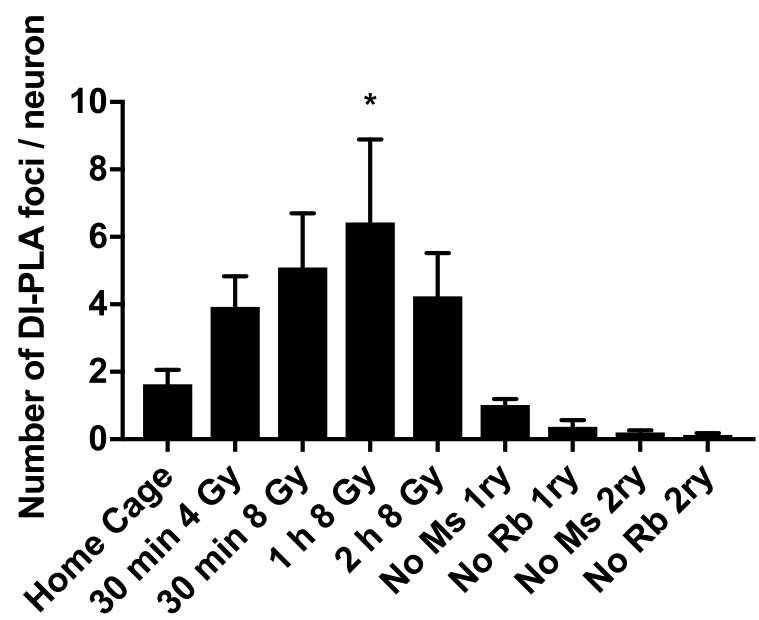

Fig. 6 DI-PLA detects DSBs in neurons of mice exposed to ionizing radiation. a Schematic of the DI-PLA. A biotinylated (green circle) linker (light blue) is ligated to the free ends of a DSB (black lines). An antibody (black) against biotin and an antibody from a different species (dark blue) against a DSB-associated repair factor (purple oval) are then added. Species-specific secondary antibodies (pink and orange) conjugated to DNA oligonucleotides are used to detect the primary antibodies. If the primary antibody targets are located in close proximity, a connector oligonucleotide ligates them to one another and allows for the creation of a closed circular DNA template that can be amplified by rolling circle amplification. Fluorescently labeled oligonucleotides (red hexagons) hybridize to the amplicon and can be visualized by fluorescence microscopy. $\mathbf{b}$ Representative confocal images of DI-PLA signals and NeuN immunostaining in somatosensory cortex sections from 3 to 6-month-old mice that were untreated (Home Cage, top) or exposed to 8 Gy whole-body ionizing radiation $1 \mathrm{~h}$ before analysis (bottom). DI-PLA single channel (left) and merged views (right) are shown. Scale bar: $10 \mu \mathrm{m}$. c Number of DI-PLA foci per neuron in somatosensory cortex from mice analyzed at different time points after 4 Gy or 8 Gy irradiation. Besides unirradiated mice, negative controls included the omission of mouse (Ms) or rabbit (Rb) primary antibodies (1 ry) and of mouse or rabbit secondary antibodies (2ry). $n=4-5$ mice per group. ${ }^{*} p<0.05$ vs. Home Cage by one-way ANOVA and Holm-Sidak test. Bars represent means \pm SEM

kainate-induced seizure activity in mice resulted in pan-nuclear H2AX phosphorylation rather than DSB formation. This finding casts doubt on the role of acute epileptic activity as a potential cause of DSBs, although it cannot exclude the possibility that chronic epileptic activity or other types of network dysfunction contribute to DSB formation in AD and related conditions. Several recent studies have demonstrated an increase in the level of transposable elements in Alzheimer's disease and other neurodegenerative tauopathies [26, 107]. As some transposons can cause DSBs through endogenous endonuclease activity [24], their increase might also contribute to the increase in DSBs we observed in MCI and AD.

Interestingly, AD patients show evidence for DNA repair deficits even in peripheral blood cells $[11,19]$ and several proteins with known roles in DSB repair are depleted in their brains [7, 41, 95, 98, 105]. Thus, deficits in DNA repair may also contribute to the abnormal neuronal accumulation of DSBs in AD. Several environmental factors, including viruses and a high fat diet, have been linked to the weakened DNA repair in AD. For example, several 

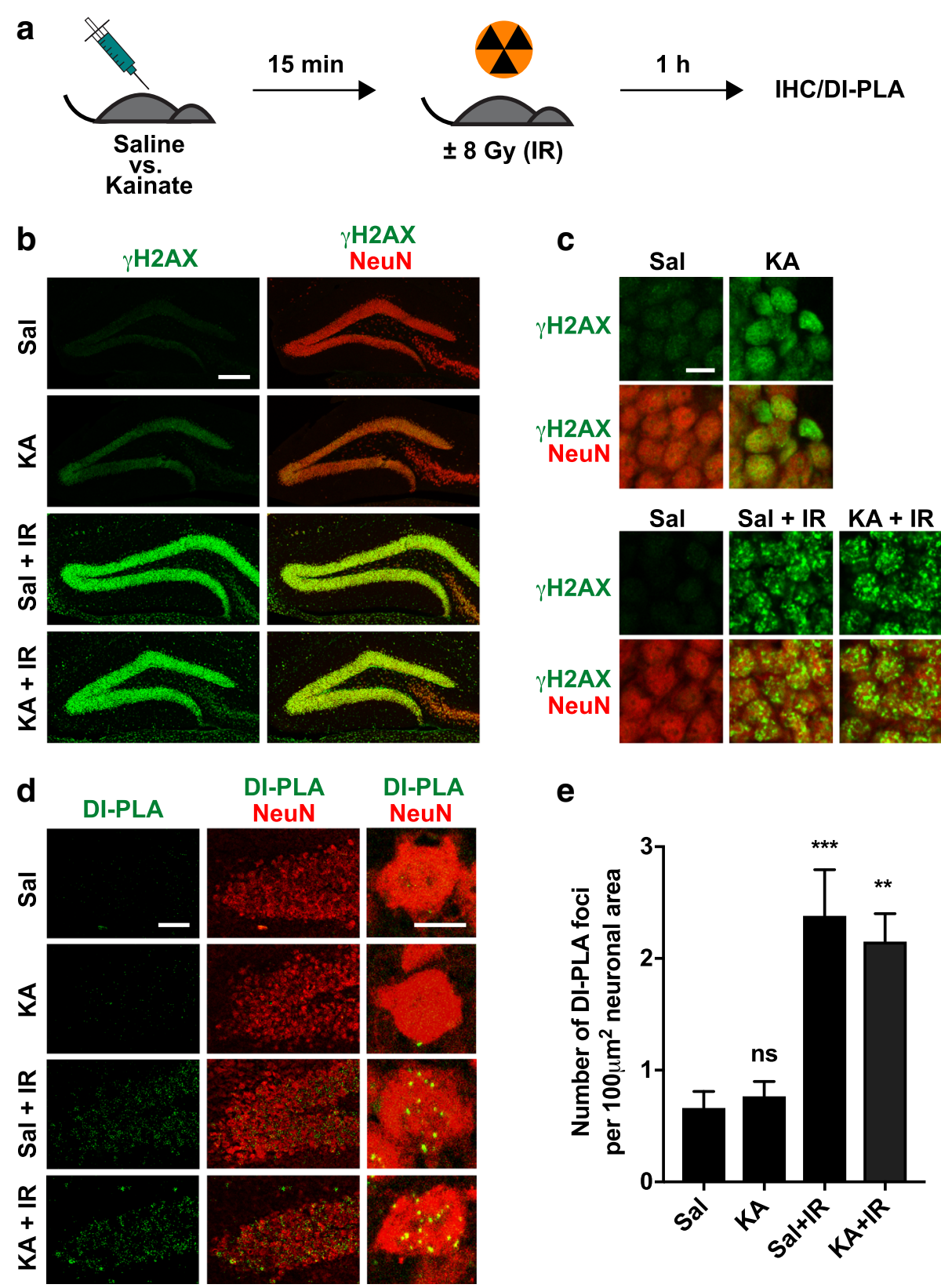

Fig. 7 Experimental differentiation between focal and pan-nuclear neuronal $\gamma \mathrm{H} 2 \mathrm{AX}$ labeling. a Schematic of experimental design. Mice received an intraperitoneal injection of kainate (KA, $20 \mathrm{mg} / \mathrm{kg}$ ) or saline (Sal) at 3-6 months of age. Fifteen minutes later, roughly half of them were exposed to 8 Gy ionizing radiation (IR). One hour later, all mice were sacrificed and their brains processed for fluorescence immunohistochemistry (b, c) and DI-PLA (d, e). b Representative confocal images of dentate gyrus sections co-labeled for $\gamma \mathrm{H} 2 \mathrm{AX}$ and NeuN. $\gamma \mathrm{H} 2 \mathrm{AX}$ single channel (left) and merged views (right) are shown. Scale bar: $200 \mu \mathrm{m}$. c Representative higher magnification views of sections similar to those in (b). Scale bar: $10 \mu \mathrm{m}$. $\mathbf{d}$ Representative confocal images from the apex of the dentate gyrus showing DI-PLA signals (left) and merged views with NeuN co-labeling (middle). High-magnification images (right) show individual neurons with DI-PLA signals (green) and NeuN immunostaining (red). Scale bar: $50 \mu m$ (left and middle), $10 \mu \mathrm{m}$ (right). e Number of DI-PLA foci per $100 \mu \mathrm{m}^{2}$ neuronal area in the apex of the dentate gyrus. $n=4-7$ mice per group. Two-way ANOVA revealed an effect of irradiation $(p<0.0001)$ but not of kainate $(p=0.8093)$ and no interaction between them $(p=0.5201) .{ }^{* *} p<0.01,{ }^{* *} p<0.001$ vs. Sal by Holm-Sidak test. Bars represent means \pm SEM

studies have found increased evidence for the presence of viral pathogens in $\mathrm{AD}$ brains, particularly herpes simplex viruses (HSV) and human herpesvirus 6 (HHV6) [9, 37, 52, 61, 89]. Infection with HSV1 can cause DNA damage in neurons, including DSBs [17], and impair DNA repair by NHEJ $[17,50,86]$. A recent study found that a high fat diet increased neuronal DSB levels and altered the balance of DSB repair pathways in aged APP/PSEN1 mice [118]. It 
is tempting to speculate that this process may contribute to the accelerated cognitive decline observed in APP/PSEN1 mice on this diet $[104,109,114]$.

Because 53BP1 promotes the repair of DNA damage, including DSBs [38, 77, 116, 117], the absence of 53BP1-positive foci in neurons of $\mathrm{MCI}$ and $\mathrm{AD}$ cases with clear evidence for DSBs by $\gamma \mathrm{H} 2 \mathrm{AX}$ immunostaining in our study could, in principle, represent a DNA repair deficit in AD. Specifically, recruitment of 53BP1 to DSBs may be defective in AD. Such a recruitment defect would be consistent with a recent report of decreased 53BP1 foci at DSBs in models of C9orf72 repeat expansion, a common cause of amyotrophic lateral sclerosis and frontotemporal lobar degeneration [113]. This decrease in 53BP1 foci was attributed, in part, to deficits in ubiquitin signaling [113], which is required for the maintenance of 53BP1 at DSBs [15, 40, 63, 66]. Abnormalities in ubiquitin-proteasome functions have also been detected in brains of patients with $\mathrm{AD}[44,45,56]$, which may explain why we did not find 53BP1 accumulation at DSBs in this condition. However, $\gamma \mathrm{H} 2 \mathrm{AX}$ foci in neurons of cognitively unimpaired controls also did not colocalize with 53BP1 (data not shown). This finding raises the possibility that 53BP1 fulfills different functions in humans than in mice, in which induction of DSBs consistently resulted in the formation of nuclear foci containing both $\gamma \mathrm{H} 2 \mathrm{AX}$ and 53BP1. It is unlikely that the absence of 53BP1 foci in human AD cases represents a postmortem artifact, as neuronal 53BP1 foci could be readily identified in brains of irradiated mice even after prolonged PMIs and when using similar tissue fixation conditions as in the human cases. It is also unlikely that AD depletes neuronal 53BP1 levels, as we found diffuse pan-nuclear increases in 53BP1 immunoreactivity in neurons of $\mathrm{MCI}$ and $\mathrm{AD}$ cases, as compared to controls.

In the process of quantifying DSBs in $\mathrm{MCI}$ and $\mathrm{AD}$, we observed that $\gamma \mathrm{H} 2 \mathrm{AX}$ can also exist in a diffuse pan-nuclear pattern in neurons that is distinct from its focal accumulation at DSBs. We also found increases in pan-nuclear $\gamma \mathrm{H} 2 \mathrm{AX}$ in non-neuronal cells in $\mathrm{AD}$ brains, consistent with a previous report [76]. Similar pan-nuclear increases in $\gamma \mathrm{H} 2 \mathrm{AX}$ formation have been reported in the context of irradiation-induced apoptosis in resting human lymphocytes [18], in response to certain types of DNA damage in the absence of apoptosis in dividing cell lines and cultured primary cells [28, 74], after cellular infection of dividing cell lines with inactivated adeno-associated viral particles [21], and after treatment with a high-dose alkylating agent in a human amnion cell line [119].

Here, we were able to experimentally elicit pan-nuclear increases in $\gamma \mathrm{H} 2 \mathrm{AX}$ immunoreactivity in vitro and in vivo by increasing neuronal activity. In kainate-treated mice and in cultured neurons treated with bicuculline, most neurons with increased pan-nuclear $\gamma \mathrm{H} 2 \mathrm{AX}$ showed no evidence of DSBs by DI-PLA or neutral comet assay, suggesting that pan-nuclear and focal increases in $\gamma \mathrm{H} 2 \mathrm{AX}$ have different causes and functions. In line with this conclusion, low doses of the alkylating agent $\mathrm{N}$-methyl- $\mathrm{N}^{\prime}$-nitro- $\mathrm{N}$-nitrosoguanidine (MNNG) caused the formation of $\gamma \mathrm{H} 2 \mathrm{AX}$ foci and a positive neutral comet assay suggestive of DSBs in a dividing cell line, whereas higher doses of MNNG led to pan-nuclear H2AX phosphorylation without evidence for DSBs by neutral comet assay [119].

Because we detected particularly high levels of pannuclear $\gamma \mathrm{H} 2 \mathrm{AX}$ in fast-spiking interneurons at baseline, it is tempting to speculate that high levels of pan-nuclear $\gamma \mathrm{H} 2 \mathrm{AX}$ somehow support or result from high levels of physiological neuronal activity in vivo. Additional studies are needed to test these hypotheses and to unravel the mechanisms involved. Notwithstanding these uncertainties, our findings clearly demonstrate that increases in overall levels of neuronal $\gamma \mathrm{H} 2 \mathrm{AX}$-as measured, for example, by western blot analysis-should not be interpreted as evidence for DSB accumulation, because such increases can result from changes in neuronal activity, and possibly other processes, in the absence of DSBs.

\section{Conclusions}

Our study demonstrates that DSBs accumulate in neurons and astrocytes at early stages and during the progression of $\mathrm{AD}$, a process that may contribute to neuronal dysfunction and degeneration. Further investigation of the causes and consequences of DSBs and other types of DNA damage in $\mathrm{AD}$ and related conditions may identify novel opportunities for therapeutic intervention.

\section{Additional file}

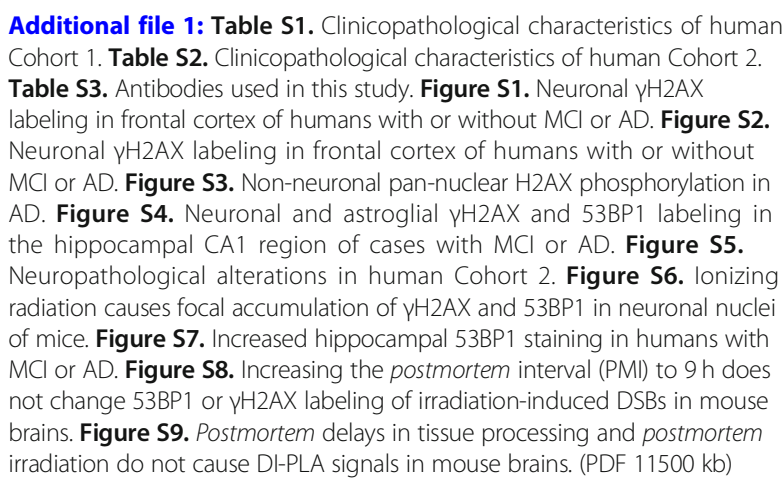

\section{Abbreviations}

AD: Alzheimer's disease; A $\beta$ : Amyloid- $\beta$; Bic: Bicuculline; Ctl: Control;

DAB: Diaminobenzidine; DI-PLA: DNA damage in situ ligation followed by proximity ligation assay; DSBs: DNA double strand breaks; ETP: Etoposide;

FITC: Fluorescein isothiocyanate; HHV6: Human herpesvirus 6; HRP: Horseradish peroxidase; HSV: Herpes simplex viruses;

ICC: Immunocytochemistry; IHC: Immunohistochemistry; IR: Ionizing radiation; 
KA: Kainate; MCl: Mild cognitive impairment; MMSE: Mini-mental state examination; MNNG: N-methyl-N'-nitro-N-nitrosoguanidine; NHEJ: Nonhomologous end joining; PBS: Phosphate-buffered saline; PFA: Paraformaldehyde; PMI: Postmortem intervals; ROI: Regions of interest; Sal: Saline; TBS: Tris-buffered saline; TBST: Tris-buffered saline containing 0.1\% Tween-20; TSA: Tyramide signal amplification; TTX: Tetrodotoxin

\section{Acknowledgements}

We thank Fabrizio d'Adda di Fagagna for helpful discussion and Randi Mott for administrative assistance.

\section{Funding}

This study was supported by US National Institutes of Health grants AG011385 and AG053981 (to LM), NS070680 (to NMS), and AG05131 and AG18440 (to RR), Alzheimer's Association grant AARF-16-441393 (to NMS), and a gift from the Ray and Dagmar Dolby Family Fund (to LM). The UCSF Neurodegenerative Disease Brain Bank was supported by NIH grants AG023501 and AG019724, the Tau Consortium, and the Bluefield Project to Cure FTD.

\section{Availability of data and materials}

All data supporting this study are available from the corresponding author upon reasonable request.

\section{Authors' contributions}

NMS, MDE, WM, EM, and LM designed the study. NMS, MDE, WM, AA, RR, and EM conducted the experiments. ANL and WS contributed human tissue samples. NMS, MDE, WM, EM and LM analyzed the data. NMS, MDE, WM, and LM wrote the manuscript with input from the other coauthors. All authors have read and approved the final manuscript.

\section{Ethics approval and consent to participate}

All studies involving human participants were in accordance with the Declaration of Helsinki, and all procedures were approved by the UCSF Committee on Human Research and the UCSD Institutional Review Board. All studies involving animals were in accordance with $\mathrm{NIH}$ guidelines and all procedures were approved by the UCSF Institutional Animal Care and Use Committee.

\section{Consent for publication}

Not applicable.

\section{Competing interests}

The authors declare that they have no competing interests.

\section{Publisher's Note}

Springer Nature remains neutral with regard to jurisdictional claims in published maps and institutional affiliations.

\section{Author details}

${ }^{1}$ Gladstone Institute of Neurological Disease, San Francisco, CA 94158, USA. ${ }^{2}$ Memory and Aging Center, Department of Neurology, University of California San Francisco, San Francisco, CA 94158, USA. ${ }^{3}$ Department of Pathology, University of California San Francisco, San Francisco, CA 94158, USA. ${ }^{4}$ Department of Neurosciences, University of California at San Diego, La Jolla, CA 92093, USA. ${ }^{5}$ Present address: Division of Neuroscience, National Institute on Aging, Bethesda, MD 20892, USA.

Received: 12 April 2019 Accepted: 16 April 2019

Published online: 17 May 2019

\section{References}

1. Bakker A, Albert MS, Krauss G, Speck CL, Gallagher M (2015) Response of the medial temporal lobe network in amnestic mild cognitive impairment to therapeutic intervention asessed by fMRI and memory task performance. Neuroimage Clin 7:688-698

2. Bakker A, Krauss GL, Albert MS, Speck CL, Jones LR, Stark CE et al (2012) Reduction of hippocampal hyperactivity improves cognition in amnestic mild cognitive impairment. Neuron 74:467-474. https://doi.org/10.1016/j. neuron.2012.03.023
3. Belyaev IY, Eriksson S, Nygren J, Torudd J, Harms-Ringdahl M (1999) Effects of ethidium bromide on DNA loop organisation in human lymphocytes measured by anomalous viscosity time dependence and single cell gel electrophoresis. Biochim Biophys Acta 1428:348-356

4. Bennett CB, Lewis AL, Baldwin KK, Resnick MA (1993) Lethality induced by a single site-specific double-strand break in a dispensable yeast plasmid. Proc Natl Acad Sci U S A 90:5613-5617

5. Berkovich E, Monnat RJ Jr, Kastan MB (2007) Roles of ATM and NBS1 in chromatin structure modulation and DNA double-strand break repair. Nat Cell Biol 9:683-690. https://doi.org/10.1038/ncb1599

6. Bradley-Whitman MA, Timmons MD, Beckett TL, Murphy MP, Lynn BC, Lovell MA (2014) Nucleic acid oxidation: an early feature of Alzheimer's disease. J Neurochem 128:294-304. https://doi.org/10.1111/jnc.12444

7. Bucholtz N, Demuth I (2013) DNA-repair in mild cognitive impairment and Alzheimer's disease. DNA Repair 12:811-816. https://doi.org/10.1016/j. dnarep.2013.07.005

8. Butterfield DA, Drake J, Pocernich C, Castegna A (2001) Evidence of oxidative damage in Alzheimer's disease brain: central role for amyloid bpeptide. Trends Mol Med 7:548-554

9. Carbone I, Lazzarotto T, lanni M, Porcellini E, Forti P, Masliah E et al (2014) Herpes virus in Alzheimer's disease: relation to progression of the disease. Neurobiol Aging 35:122-129. https://doi.org/10.1016/j.neurobiolaging.2013.06.024

10. Chen J, Cohen ML, Lerner AJ, Yang Y, Herrup K (2010) DNA damage and cell cycle events implicate cerebellar dentate nucleus neurons as targets of Alzheimer's disease. Mol Neurodegener 5:60. https://doi.org/ 10.1186/1750-1326-5-60

11. Chen SK, Hsieh WA, Tsai MH, Chen CC, Hong Al, Wei YH et al (2003) Ageassociated decrease of oxidative repair enzymes, human 8-oxoguanine DNA glycosylases (hOgg1), in human aging. J Radiat Res 44:31-35

12. Cooke MS, Evans MD, Dizdaroglu M, Lunec J (2003) Oxidative DNA damage: mechanisms, mutation, and disease. FASEB J 17:1195-1214. https://doi.org/ 10.1096/fj.02-0752rev

13. Corbett BF, You JC, Zhang X, Pyfer MS, Tosi U, lascone DM et al (2017) DeltaFosB regulates gene expression and cognitive dysfunction in a mouse model of Alzheimer's Disease. Cell Rep 20:344-355. https://doi.org/10.1016/j. celrep.2017.06.040

14. Crosetto N, Mitra A, Silva MJ, Bienko M, Dojer N, Wang Q et al (2013) Nucleotide-resolution DNA double-strand break mapping by next-generation sequencing. Nat Methods 10:361-365. https://doi.org/10.1038/nmeth.2408

15. Dantuma NP, Groothuis TA, Salomons FA, Neefjes J (2006) A dynamic ubiquitin equilibrium couples proteasomal activity to chromatin remodeling. J Cell Biol 173:19-26. https://doi.org/10.1083/jcb.200510071

16. De Bont $R$, van Larebeke N (2004) Endogenous DNA damage in humans: a review of quantitative data. PubMed 19:169-185

17. De Chiara G, Racaniello M, Mollinari C, Marcocci ME, Aversa G, Cardinale A et al (2016) Herpes simplex virus-Type1 (HSV-1) impairs DNA repair in cortical neurons. Front Aging Neurosci 8:1-12. https://doi.org/10.3389/fnagi.2016.00242

18. Ding D, Zhang Y, Wang J, Zhang X, Gao Y, Yin L et al (2016) Induction and inhibition of the pan-nuclear gamma-H2AX response in resting human peripheral blood lymphocytes after X-ray irradiation. Cell Death Discov 2:110. https://doi.org/10.1038/cddiscovery.2016.11

19. Dorszewska J, Kempisty B, Jaroszewska-Kolecka J, Rozycka A, Florczak J, Lianeri $\mathrm{M}$ et al (2009) Expression and polymorphisms of gene 8-oxoguanine glycosylase 1 and the level of oxidative DNA damage in peripheral blood lymphocytes of patients with Alzheimer's disease. DNA Cell Biol 28:579-588. https://doi.org/10.1089/dna.2009.0926

20. Ferguson DO, Alt FW (2001) DNA double strand break repair and chromosomal translocation: lessons from animal models. Oncogene 20: 5572-5579. https://doi.org/10.1038/sj.onc.1204767

21. Fragkos M, Jurvansuu J, Beard P (2009) H2AX is required for cell cycle arrest via the p53/p21 pathway. Mol Cell Biol 29:2828-2840. https://doi.org/10. 1128/MCB.01830-08

22. Gabbita SP, Lovell MA, Markesbery WR (1998) Increased nuclear DNA oxidation in the brain in Alzheimer's disease. J Neurochem 71:2034-2040

23. Galbiati A, Beauséjour C, d'Adda di Fagagna F (2017) A novel single-cell method provides direct evidence of persistent DNA damage in senescent cells and aged mammalian tissues. Aging Cell 16:422-427. https://doi.org/ 10.1111/acel.12573

24. Gasior SL, Wakeman TP, Xu B, Deininger PL (2006) The human LINE-1 retrotransposon creates DNA double-strand breaks. J Mol Biol 357:13831393. https://doi.org/10.1016/j.jmb.2006.01.089 
25. Götz ME, Kunig G, Riederer P, Youdim MB (1994) Oxidative stress: free radical production in neural degeneration. PharmacolTherap 63:37-122

26. Guo C, Jeong HH, Hsieh YC, Klein HU, Bennett DA, De Jager PL et al (2018) Tau activates transposable elements in Alzheimer's Disease. Cell Rep 23: 2874-2880. https://doi.org/10.1016/j.celrep.2018.05.004

27. Halliwell B, Aruoma OI (1991) DNA damage by oxygen-derived species. Its mechanism and measurement in mammalian systems. FEBS Lett 281:9-19

28. Horn S, Brady D, Prise K (2015) Alpha particles induce pan-nuclear phosphorylation of $\mathrm{H} 2 \mathrm{AX}$ in primary human lymphocytes mediated through ATM. Biochim Biophys Acta 1853:2199-2206. https:/doi.org/10.1016/j.bbamcr.2015.06.010

29. Hornsby PJ, Didenko W (2011) In situ ligation: a decade and a half of experience. Methods Mol Biol 682:49-63. https://doi.org/10.1007/978-160327-409-8_5

30. Horváth A, Szucs A, Barcs G, Kamondi A (2017) Sleep EEG detects epileptiform activity in Alzheimer's disease with high sensitivity. J Alzheimers Dis 56:1175-1183. https://doi.org/10.3233/JAD-160994

31. Hou Y, Song H, Croteau DL, Akbari M, Bohr VA (2017) Genome instability in Alzheimer disease. Mech Ageing Dev 161:83-94. https://doi.org/10.1016/j. mad.2016.04.005

32. Hu H, Gan J, Jonas P (2014) Fast-spiking, parvalbumin+ GABAergic interneurons: from cellular design to microcircuit function. Science 345 : 1255263-1255263. https://doi.org/10.1126/science.1255263

33. Hyman BT, Phelps CH, Beach TG, Bigio EH, Cairns NJ, Carrillo MC et al (2012) National Institute on Aging-Alzheimer's Association guidelines for the neuropathologic assessment of Alzheimer's disease. Alzheimers Dement 8 : 1-13. https://doi.org/10.1016/j.jalz.2011.10.007

34. lacopino AM, Christakos S (1990) Specific reduction of calcium-binding protein (28-kilodalton calbindin-D) gene expression in aging and neurodegenerative diseases. Proc Natl Acad Sci U S A 87:4078-4082

35. lacovoni JS, Caron P, Lassadi I, Nicolas E, Massip L, Trouche D et al (2010) High-resolution profiling of gammaH2AX around DNA double strand breaks in the mammalian genome. EMBO J 29:1446-1457. https://doi.org/10.1038/ emboj.2010.38

36. Iannelli F, Galbiati A, Capozzo I, Nguyen Q, Magnuson B, Michelini F et al (2017) A damaged genome's transcriptional landscape through multilayered expression profiling around in situ-mapped DNA double-strand breaks. Nat Commun 8:1-12. https://doi.org/10.1038/ncomms15656

37. Itzhaki RF, Lin W-R, Shang D, Wilcock GK, Faragher B, Jamieson GA (1997) Herpes simplex virus type 1 in brain and risk of Alzheimer's disease. Lancet 349:241-244. https://doi.org/10.1016/s0140-6736(96)10149-5

38. Iwabuchi K, Hashimoto M, Matsui T, Kurihara T, Shimizu H, Adachi N et al (2006) 53BP1 contributes to survival of cells irradiated with X-ray during G1 without Ku70 or Artemis. Genes Cells 11:935-948. https://doi.org/10.1111/j. 1365-2443.2006.00989.x

39. Iyama T, Wilson DM 3rd (2013) DNA repair mechanisms in dividing and non-dividing cells. DNA Repair (Amst) 12:620-636. https://doi.org/10.1016/j. dnarep.2013.04.015

40. Jackson SP, Durocher D (2013) Regulation of DNA damage responses by ubiquitin and SUMO. Mol Cell 49:795-807. https://doi.org/10.1016/j.molcel. 2013.01.017

41. Jacobsen E, Beach T, Shen Y, Li R, Chang Y (2004) Deficiency of the Mre11 DNA repair complex in Alzheimer's disease brains. Brain Res Mol Brain Res 128:1-7. https://doi.org/10.1016/j.molbrainres.2004.05.023

42. Jeppesen DK, Bohr VA, Stevnsner T (2011) DNA repair deficiency in neurodegeneration. Prog Neurobiol 94:166-200. https://doi.org/10.1016/j. pneurobio.2011.04.013

43. Katsube T, Mori M, Tsuji H, Shiomi T, Wang B, Liu Q et al (2014) Most hydrogen peroxide-induced histone $\mathrm{H} 2 \mathrm{AX}$ phosphorylation is mediated by ATR and is not dependent on DNA double-strand breaks. J Biochem 156: 85-95. https://doi.org/10.1093/jb/mvu021

44. Keck S, Nitsch R, Grune T, Ullrich O (2003) Proteasome inhibition by paired helical filament-tau in brains of patients with Alzheimer's disease. J Neurochem 85:115-122. https://doi.org/10.1046/j.1471-4159. 2003.01642.x

45. Keller JN, Hanni KB, Markesbery WR (2000) Impaired proteasome function in Alzheimer's disease. J Neurochem 75:436-439

46. Korolev IO, Symonds LL, Bozoki AC, Alzheimer's Disease Neuroimaging I (2016) Predicting progression from mild cognitive impairment to Alzheimer's dementia using clinical, MRI, and plasma biomarkers via probabilistic pattern classification. PLoS One 11:E0138866. https://doi.org/10. 1371/journal.pone.0138866
47. Kruhlak M, Crouch EE, Orlov M, Montano C, Gorski SA, Nussenzweig A et al (2007) The ATM repair pathway inhibits RNA polymerase I transcription in response to chromosome breaks. Nature 447:730-734. https://doi.org/10. 1038/nature05842

48. Lam AD, Deck G, Goldman A, Eskandar EN, Noebels J, Cole AJ (2017) Silent hippocampal seizures and spikes identified by foramen ovale electrodes in Alzheimer's disease. Nat Med 23:678-680. https://doi.org/10.1038/nm.4330

49. Lee MH, Siddoway B, Kaeser GE, Segota I, Rivera R, Romanow WJ et al (2018) Somatic APP gene recombination in Alzheimer's disease and normal neurons. Nature: Doi. https://doi.org/10.1038/s41586-018-0718-6

50. Lees-Miller SP, Long MC, Kilvert MA, Lam V, Rice SA, Spencer CA (1996) Attenuation of DNA-dependent protein kinase activity and its catalytic subunit by the herpes simplex virus type 1 transactivator ICPO. J Virol 70:7471-7477

51. Lieber MR (2010) The mechanism of double-strand DNA break repair by the nonhomologous DNA end-joining pathway. Annu Rev Biochem 79:181-211. https://doi.org/10.1146/annurev.biochem.052308.093131

52. Lin WR, Wozniak MA, Cooper RJ, Wilcock GK, Itzhaki RF (2002) Herpesviruses in brain and Alzheimer's disease. J Pathol 197:395-402. https://doi.org/10. 1002/path.1127

53. Lindahl T, Barnes DE (2000) Repair of endogenous DNA damage. Cold Spring Harb Symp Quant Biol 65:127-133

54. Lobrich M, Shibata A, Beucher A, Fisher A, Ensminger M, Goodarzi AA et al (2010) gammaH2AX foci analysis for monitoring DNA double-strand break repair: strengths, limitations and optimization. Cell Cycle 9:662-669. https:// doi.org/10.4161/cc.9.4.10764

55. Lombard DB, Chua KF, Mostoslavsky R, Franco S, Gostissa M, Alt FW (2005) DNA repair, genome stability, and aging. Cell 120:497-512. https://doi.org/ 10.1016/j.cell.2005.01.028

56. López Salon M, Morelli L, Castaño EM, Soto EF, Pasquini JM (2000) Defective ubiquitination of cerebral proteins in Alzheimer's disease. J Neurosci Res 62:302-310. https://doi.org/10.1002/1097-4547(20001015)62: 2<302::AID-JNR15>3.0.CO;2-L

57. Lopez-Otin C, Blasco MA, Partridge L, Serrano M, Kroemer G (2013) The hallmarks of aging. Cell 153:1194-1217. https://doi.org/10.1016/j.cell.2013.05.039

58. Lovell MA, Gabbita SP, Markesbery WR (1999) Increased DNA oxidation and decreased levels of repair products in Alzheimer's disease ventricular CSF. J Neurochem 72:771-776

59. Lovell MA, Markesbery WR (2007) Oxidative damage in mild cognitive impairment and early Alzheimer's disease. J Neurosci Res 85:3036-3040. https://doi.org/10.1002/jnr.21346

60. Lovell MA, Markesbery WR (2007) Oxidative DNA damage in mild cognitive impairment and late-stage Alzheimer's disease. Nucleic Acids Res 35:74977504. https://doi.org/10.1093/nar/gkm821

61. Lovheim H, Gilthorpe J, Adolfsson R, Nilsson LG, Elgh F (2015) Reactivated herpes simplex infection increases the risk of Alzheimer's disease. Alzheimers Dement 11:593-599. https://doi.org/10.1016/j.jalz.2014.04.522

62. Lu T, Pan Y, Kao SY, Li C, Kohane I, Chan J et al (2004) Gene regulation and DNA damage in the ageing human brain. Nature 429:883-891. https://doi. org/10.1038/nature02661

63. Lukas J, Lukas C, Bartek J (2011) More than just a focus: the chromatin response to DNA damage and its role in genome integrity maintenance. Nat Cell Biol 13:1161-1169. https://doi.org/10.1038/ncb2344

64. Madabhushi R, Gao F, Pfenning AR, Pan L, Yamakawa S, Seo J et al (2015) Activity-induced DNA breaks govern the expression of neuronal early-response genes. Cell 161:1592-1605. https://doi.org/10.1016/j.cell.2015.05.032

65. Madabhushi R, Pan L, Tsai LH (2014) DNA damage and its links to neurodegeneration. Neuron 83:266-282. https://doi.org/10.1016/j.neuron. 2014.06.034

66. Mailand N, Bekker-Jensen S, Faustrup H, Melander F, Bartek J, Lukas C et al (2007) RNF8 ubiquitylates histones at DNA double-strand breaks and promotes assembly of repair proteins. Cell 131:887-900. https://doi.org/10. 1016/j.cell.2007.09.040

67. Manly JJ, Tang MX, Schupf N, Stern Y, Vonsattel JP, Mayeux R (2008) Frequency and course of mild cognitive impairment in a multiethnic community. Ann Neurol 63:494-506. https://doi.org/10.1002/ana.21326

68. Mano T, Nagata K, Nonaka T, Tarutani A, Imamura T, Hashimoto T et al (2017) Neuron-specific methylome analysis reveals epigenetic regulation and tau-related dysfunction of BRCA1 in Alzheimer's disease. Proc Natl Acad Sci U S A 114:E9645-E9654. https://doi.org/10.1073/pnas.1707151114

69. Mark RJ, Blanc EM, Mattson MP (1996) Amyloid b-peptide and oxidative cellular injury in Alzheimer's disease. Mol Neurobiol 12:211-224 
70. McKeith IG, Dickson DW, Lowe J, Emre M, O'Brien JT, Feldman H et al (2005) Diagnosis and management of dementia with Lewy bodies: third report of the DLB consortium. Neurology 65:1863-1872

71. McKinnon PJ (2009) DNA repair deficiency and neurological disease. Nat Rev Neurosci 10:100-112. https://doi.org/10.1038/nrn2559

72. McLachlan DR, Wong L, Bergeron C, Baimbridge KG (1987) Calmodulin and calbindin D28K in Alzheimer disease. Alzheimer Dis Assoc Disord 1:171-179

73. McManus KJ, Hendzel MJ (2005) ATM-dependent DNA damage-independent mitotic phosphorylation of $\mathrm{H} 2 \mathrm{AX}$ in normally growing mammalian cells. Mol Biol Cell 16:5013-5025. https://doi.org/10.1091/mbc.E05-01-0065

74. Meyer B, Voss KO, Tobias F, Jakob B, Durante M, Taucher-Scholz G (2013) Clustered DNA damage induces pan-nuclear H2AX phosphorylation mediated by ATM and DNA-PK. Nucleic Acids Res 41:6109-6118. https://doi. org/10.1093/nar/gkt304

75. Miyamoto T, Stein L, Thomas R, Djukic B, Taneja P, Knox J et al (2017) Phosphorylation of tau at $Y 18$, but not tau-fyn binding, is required for tau to modulate NMDA receptor-dependent excitotoxicity in primary neuronal culture. Mol Neurodegener 12:41. https://doi.org/10.1186/s13024-017-0176-x

76. Myung NH, Zhu X, Kruman II, Castellani RJ, Petersen RB, Siedlak SL et al (2008) Evidence of DNA damage in Alzheimer disease: phosphorylation of histone H2AX in astrocytes. Age 30:209-215. https://doi.org/10.1007/s11357008-9050-7

77. Nakamura K, Sakai W, Kawamoto T, Bree RT, Lowndes NF, Takeda S et al (2006) Genetic dissection of vertebrate 53BP1: a major role in nonhomologous end joining of DNA double strand breaks. DNA Repair (Amst) 5:741-749. https://doi.org/10.1016/j.dnarep.2006.03.008

78. Olive PL, Banath JP (2006) The comet assay: a method to measure DNA damage in individual cells. Nat Protoc 1:23-29. https://doi.org/10.1038/nprot.2006.5

79. Olive PL, Wlodek D, Banath JP (1991) DNA double-strand breaks measured in individual cells subjected to gel electrophoresis. Cancer Res 51:4671-4676

80. Ostling O, Johanson KJ (1984) Microelectrophoretic study of radiationinduced DNA damages in individual mammalian cells. Biochem Biophys Res Commun 123:291-298. https://doi.org/10.1016/0006-291X(84)90411-X

81. Palop JJ, Jones B, Kekonius L, Chin J, Yu GQ, Raber J et al (2003) Neuronal depletion of calcium-dependent proteins in the dentate gyrus is tightly linked to Alzheimer's disease-related cognitive deficits. Proc Natl Acad Sci U S A 100:9572-9577. https://doi.org/10.1073/pnas.1133381100

82. Palop JJ, Mucke L (2016) Network abnormalities and interneuron dysfunction in Alzheimer disease. Nat Rev Neurosci 17:777-792. https://doi. org/10.1038/nrn.2016.141

83. Pan L, Penney J, Tsai LH (2014) Chromatin regulation of DNA damage repair and genome integrity in the central nervous system. J Mol Biol 426:33763388. https://doi.org/10.1016/j.jmb.2014.08.001

84. Panier S, Boulton SJ (2014) Double-strand break repair: 53BP1 comes into focus. Nat Rev Mol Cell Biol 15:7-18. https://doi.org/10.1038/nrm3719

85. Pankotai T, Bonhomme C, Chen D, Soutoglou E (2012) DNAPKcs-dependent arrest of RNA polymerase II transcription in the presence of DNA breaks. Nat Struct Mol Biol 19:276-282. https://doi.org/10.1038/nsmb.2224

86. Parkinson J, Lees-Miller SP, Everett RD (1999) Herpes simplex virus type 1 immediate-early protein vmw110 induces the proteasome-dependent degradation of the catalytic subunit of DNA-dependent protein kinase. $J$ Virol 73:650-657

87. Pham E, Crews L, Ubhi K, Hansen L, Adame A, Cartier A et al (2010) Progressive accumulation of amyloid-beta oligomers in Alzheimer's disease and in amyloid precursor protein transgenic mice is accompanied by selective alterations in synaptic scaffold proteins. FEBS J 277:3051-3067. https://doi.org/10.1111/j.1742-4658.2010.07719.x

88. Pospelova TV, Demidenko ZN, Bukreeva El, Pospelov VA, Gudkov AV, Blagosklonny MV (2009) Pseudo-DNA damage response in senescent cells. Cell Cycle 8:4112-4118

89. Readhead B, Haure-Mirande JV, Funk CC, Richards MA, Shannon P, Haroutunian $V$ et al (2018) Multiscale analysis of independent Alzheimer's cohorts finds disruption of molecular, genetic, and clinical networks by human herpesvirus. Neuron 99:64-82. https://doi.org/10. 1016/j.neuron.2018.05.023

90. Rogakou EP, Boon C, Redon C, Bonner WM (1999) Megabase chromatin domains involved in DNA double-strand breaks in vivo. J Cell Biol 146:905-916

91. Rogakou EP, Pilch DR, Orr AH, Ivanova VS, Bonner WM (1998) DNA doublestranded breaks induce histone H2AX phosphorylation on serine 139. J Biol Chem 273:5858-5868
92. Rolig RL, McKinnon PJ (2000) Linking DNA damage and neurodegeneration. Trends Neurosci 23:417-724

93. Schneider CA, Rasband WS, Eliceiri KW (2012) NIH image to ImageJ: 25 years of image analysis. Nat Methods 9:671-675

94. Sedelnikova OA, Redon CE, Dickey JS, Nakamura AJ, Georgakilas AG, Bonner WM (2010) Role of oxidatively induced DNA lesions in human pathogenesis. Mutat Res 704:152-159. https://doi.org/10.1016/j.mrrev.2009.12.005

95. Shackelford DA (2006) DNA end joining activity is reduced in Alzheimer's disease. Neurobiol Aging 27:596-605. https://doi.org/10.1016/j. neurobiolaging.2005.03.009

96. Shanbhag NM, Rafalska-Metcalf IU, Balane-Bolivar C, Janicki SM, Greenberg RA (2010) ATM-dependent chromatin changes silence transcription in cis to DNA double-strand breaks. Cell 141:970-981. https:/doi.org/10.1016/j.cell.2010.04.038

97. Sharma V, Collins LB, Chen TH, Herr N, Takeda S, Sun W et al (2016) Oxidative stress at low levels can induce clustered DNA lesions leading to NHEJ mediated mutations. Oncotarget 7:25377-25390. https://doi.org/10.18632/oncotarget.8298

98. Shen X, Chen J, Li J, Kofler J, Herrup K (2016) Neurons in vulnerable regions of the Alzheimer's Disease brain display reduced ATM signaling. eNeuro 3:1-18. https://doi.org/10.1523/ENEURO.0124-15.2016

99. Shroff R, Arbel-Eden A, Pilch D, Ira G, Bonner WM, Petrini JH et al (2004) Distribution and dynamics of chromatin modification induced by a defined DNA double-strand break. Curr Biol 14:1703-1711. https://doi.org/10.1016/j. cub.2004.09.047

100. Simpson JE, Ince PG, Haynes LJ, Theaker R, Gelsthorpe C, Baxter L et al (2010) Population variation in oxidative stress and astrocyte DNA damage in relation to Alzheimer-type pathology in the ageing brain. Neuropathol Appl Neurobiol 36:25-40. https://doi.org/10.1111/j.1365-2990.2009.01030.x

101. Simpson JE, Ince PG, Matthews FE, Shaw PJ, Heath PR, Brayne C et al (2015) A neuronal DNA damage response is detected at the earliest stages of Alzheimer's neuropathology and correlates with cognitive impairment in the Medical Research Council's cognitive function and ageing study ageing brain cohort. Neuropathol Appl Neurobiol 41:483-496. https://doi.org/10. 1111/nan.12202

102. Singh NP, McCoy MT, Tice RR, Schneider EL (1988) A simple technique for quantitation of low levels of DNA damage in individual cells. Exp Cell Res 175:184-191

103. Small SA, Nava AS, Perera GM, Delapaz R, Stern Y (2000) Evaluating the function of hippocampal subregions with high-resolution MRI in Alzheimer's disease and aging. Microsc Res Tech 51:101-108. https://doi.org/10.1002/ 1097-0029(20001001)51:1<101::AID-JEMT11>3.0.CO;2-H

104. Studzinski CM, Li F, Bruce-Keller AJ, Fernandez-Kim SO, Zhang L, Weidner AM et al (2009) Effects of short-term Western diet on cerebral oxidative stress and diabetes related factors in APP x PS1 knock-in mice. J Neurochem 108:860-866. https://doi.org/10.1111/j.1471-4159.2008.05798.x

105. Suberbielle E, Djukic B, Evans M, Kim DH, Taneja P, Wang X et al (2015) DNA repair factor BRCA1 depletion occurs in Alzheimer brains and impairs cognitive function in mice. Nat Commun 6:8897. https://doi.org/10.1038/ncomms9897

106. Suberbielle E, Sanchez PE, Kravitz AV, Wang X, Ho K, Eilertson K et al (2013) Physiologic brain activity causes DNA double-strand breaks in neurons, with exacerbation by amyloid- $\beta$. Nat Neurosci 16:613-621. https://doi.org/10. 1038/nn.3356

107. Sun W, Samimi H, Gamez M, Zare H, Frost B (2018) Pathogenic tau-induced piRNA depletion promotes neuronal death through transposable element dysregulation in neurodegenerative tauopathies. Nat Neurosci 21:10381048. https://doi.org/10.1038/s41593-018-0194-1

108. Tartaglia MC, Sidhu M, Laluz V, Racine C, Rabinovici GD, Creighton K et al (2010) Sporadic corticobasal syndrome due to FTLD-TDP. Acta Neuropathol 119:365-374. https://doi.org/10.1007/s00401-009-0605-1

109. Theriault P, ElAli A, Rivest S (2016) High fat diet exacerbates Alzheimer's disease-related pathology in APPswe/PS1 mice. Oncotarget 7:67808-67827. https://doi.org/10.18632/oncotarget.12179

110. van Gent DC, Hoeijmakers JH, Kanaar R (2001) Chromosomal stability and the DNA double-stranded break connection. Nat Rev Genet 2:196-206. https://doi.org/10.1038/35056049

111. Vossel KA, Beagle AJ, Rabinovici GD, Shu H, Lee SE, Naasan G et al (2013) Seizures and epileptiform activity in the early stages of Alzheimer disease. JAMA Neurol 70:1158-1166. https://doi.org/10.1001/jamaneurol.2013.136

112. Vossel KA, Ranasinghe KG, Beagle AJ, Mizuiri D, Honma SM, Dowling AF et al (2016) Incidence and impact of subclinical epileptiform activity in Alzheimer's disease. Ann Neurol 80:858-870. https://doi.org/ 10.1002/ana.24794 
113. Walker C, Herranz-Martin S, Karyka E, Liao C, Lewis K, Elsayed W et al (2017) C9orf72 expansion disrupts ATM-mediated chromosomal break repair. Nat Neurosci 20:1225-1235. https://doi.org/10.1038/nn.4604

114. Walker JM, Dixit S, Saulsberry AC, May JM, Harrison FE (2017) Reversal of high fat diet-induced obesity improves glucose tolerance, inflammatory response, beta-amyloid accumulation and cognitive decline in the APP/ PSEN1 mouse model of Alzheimer's disease. Neurobiol Dis 100:87-98. https://doi.org/10.1016/j.nbd.2017.01.004

115. Wang J, Markesbery WR, Lovell MA (2006) Increased oxidative damage in nuclear and mitochondrial DNA in mild cognitive impairment. J Neurochem 96:825-832. https://doi.org/10.1111/j.1471-4159.2005.03615.x

116. Ward IM, Minn K, van Deursen J, Chen J (2003) p53 binding protein 53BP1 is required for DNA damage responses and tumor suppression in mice. Mol Cell Biol 23:2556-2563. https://doi.org/10.1128/mcb.23.7.2556-2563.2003

117. Xiong X, Du Z, Wang Y, Feng Z, Fan P, Yan C et al (2015) 53BP1 promotes microhomology-mediated end-joining in G1-phase cells. Nucleic Acids Res 43:1659-1670. https://doi.org/10.1093/nar/gku1406

118. Yu H, Harrison FE, Xia F (2018) Altered DNA repair; an early pathogenic pathway in Alzheimer's disease and obesity. Sci Rep 8:5600. https://doi.org/ 10.1038/s41598-018-23644-4

119. Yu Y, Zhu W, Diao H, Zhou C, Chen FF, Yang J (2006) A comparative study of using comet assay and gammaH2AX foci formation in the detection of $\mathrm{N}$-methyl-N'-nitro-N-nitrosoguanidine-induced DNA damage. Toxicol in Vitro 20:959-965. https://doi.org/10.1016/.tiv.2006.01.004

120. Zhou BB, Elledge SJ (2000) The DNA damage response: putting checkpoints in perspective. Nature 408:433-439. https://doi.org/10.1038/35044005

Ready to submit your research? Choose BMC and benefit from:

- fast, convenient online submission

- thorough peer review by experienced researchers in your field

- rapid publication on acceptance

- support for research data, including large and complex data types

- gold Open Access which fosters wider collaboration and increased citations

- maximum visibility for your research: over $100 \mathrm{M}$ website views per year

At $\mathrm{BMC}$, research is always in progress.

Learn more biomedcentral.com/submissions 